\title{
A VÁLLALKOZÁSOK ÖKOLÓGIAI TUDATOSSÁGA
}

Mindannyian tapasztaljuk, hogy az antropocén korában az emberiség az egész bolygónkra kiterjedő, egyre súlyosbodó ökológiai válságban él. Ezért túlnyomó részt a mainstream üzleti modell tekinthető felelősnek. A mai társadalmi-gazdasági rendszer természeti környezet helyreállítását előtérbe helyező átalakítása elengedhetetlennek tűnik, amihez az etikai nézőpontok figyelembevételére, az ökológiai értékek tiszteletére és ökológiai tudatosságra van szükség. Az 1980-as évektől kezdve egyre növekvő érdeklődés mutatkozik az ökológiai tudatosság (ecological consciousness) iránt. A fogalmat az 1960-as évek végétől kezdve különböztetik meg a környezeti tudatosságtól (environmental consciousness) olyan környezetvédő aktivisták és filozófusok, akik úgy gondolták, hogy a hagyományos természetvédő mozgalmak túl szűken értelmezik a környezeti problémákat, technikai problémákká fokozzák le azokat, ezáltal nem képesek megérteni kiváltó okaikat. A környezeti problémák valójában a modernitás társadalmi és kulturális intézményeiben megtestesülő instrumentális racionalitás elkerülhetetlen következményei, ezért új racionalitásra épülő új társadalmi és kulturális intézmények nélkül a globális katasztrófa elkerülhetetlen.

A nemzetközivel összehasonlítva a hazai szakirodalomban az ökológiai tudatosság és a vállalkozások ökológiai tudatosságának tárgyalása még kevéssé elterjedt. Ezt a hiányt hivatott enyhíteni ez az írás, amely a fogalom elméleti koncepcióit tekinti át általánosságban (többek között a mélyökológia, ökológiai közgazdaságtan, felelősségetika, spiritualitásalapú vezetés, integrál ökológia, buddhista közgazdaságtan) és a vállalkozásokra fókuszálva (például a vállalatok moralista modellje, fenntarthatóság által vezérelt, illetve természet által ihletett vállalkozások, „valóban fenntartható” üzleti modellek) egyaránt, valamint néhány kapcsolódó hazai tanulmány rövid összehasonlító elemzését adja.

Kulcsszavak: vállalkozások (business), ökológiai tudatosság (ecological consciousness), etika, felelősségvállalás, spiritualitás

\begin{abstract}
A 7 antropocén korában élünk, amelyben az embeAZri tevékenység a Föld ökoszisztémáira jelentős és globális hatást gyakorol (Crutzen - Stoermer, 2000; Steffen - Broadgate et al., 2015). Bioszféra-átalakító tevékenységünk - elsősorban a társadalmak és gazdaságok globálissá váló működése által - napjainkra olyan mértékü lett, hogy a többi fajhoz képest összehasonlíthatatlanul nagyobb arányú, káros és emberi léptékkel mérve visszafordíthatatlan változásokat eredményez. Már nem csupán a jóllétünk, hanem saját és más fajok életfeltételei forognak kockán (Pataki - Takács-Sánta, 2005; Takács-Sánta, 2004). Az egész bolygónkra kiterjedő mélyülő ökológiai válság enyhítéséhez gondolkodásunk, tudatosságunk megváltoztatása, ökológiai tudatosság, a fennálló társadalmi-gazdasági rendszer természeti környezet helyreállítását előtérbe helyező átalakítása tünik szükségesnek, hogy a gazdaság ismét a természetbe és a társadalomba „beágyazott” rendszerként müködjön (Köves - Mandják, 2014; Polányi, 1976).

Számos nagyszerü tudósnak és kutató közösségnek (többek között Rachel Carson (1974), Római Klub, E. F. Schumacher (1991), Mihajlo Mesarovic (Mesarovic - Pestel, 1974), Jan Tinbergen (1979), Stockholm Resilience Centre (Steffen - Richardson et al., 2015)) köszönhetően már csaknem fél évszázada tudjuk, hogy nem jó irányba haladunk, és ha nem változtatunk, nagyon súlyos problémák elé nézünk. Napjainkra egyértelmüvé vált, nem tagadhatjuk tovább az ökológiai válság létét, és az emberiség óriási kihívásokkal kell, hogy szembesüljön.
\end{abstract}

Az ökológiai válság konkrét és tagadhatatlan jelei bizonyítják, hogy a fennálló, növekedésen alapuló gazdasági rendszer müködőképessége hosszú távon nem tartható, hiszen feléli az erőforrásait, tönkreteszi saját alapjait, létfeltételeit. Ahogy Herman Daly (2008) írja, az ökológiai korlátokba ütköző globális növekedés nagyobb költségekkel jár, mint amennyi nyereséget képes előállítani, így végső soron nem gazdagabbá, hanem szegényebbé tesz bennünket. A napjainkban kedvelt hatékonyságnövelési törekvések sem hozhatnak megoldást, mert éppen az ellenkező hatást érik el, mint szeretnénk: egy erőforrás felhasználásának javuló hatékonysága megnöveli az adott erőforrás kínálatát, ezzel csökkenti az árát, ami a felhasznált mennyiség növekedését okozza (Jevons-paradoxon), azaz sokkal hamarabb érjük el az ökológiai korlátokat. A növekedéssel ráadásul a fejlődés elé állított másik cél, a szegénység globális csökkentése sem érhető el, mert a növekedés nem a szegény országok alapvető szükségleteit, hanem sokkal inkább a fejlett országok igényeit szolgálja ki (Daly, 2008).

A mainstream üzleti modellt tehát nem csupán időben kíséri az ökológiai válság, hanem túlnyomó részt éppen maga az uralkodó üzleti modell okozza és mélyíti a válságot. A válságjelenségek, az ökológiai helyzet kedvezőtlen változásának méretei miatt nem elégségesek a kisléptékü módosítások, javítgatások, hiszen a klímakonferenciák várakozásokat rendszeresen alulmúló eredményessége is éppen az erre irányuló törekvések sikertelenségét mutatja. Elengedhetetlen a gazdaság ökológiai átalakítása, új 
progresszív üzleti modellek kifejlesztése és alkalmazása, amelyek meghonosítják az üzleti világban az etikai nézőpontok figyelembevételét, az ökológiai értékek tiszteletét, a transzdiszciplináris megközelítéseket és az alternatív gondolkodási és viselkedési módokat (Zsolnai, 2015a; Rockström, 2010).

A tanulmány a gazdasági rendszer fogyasztási javakat és szolgáltatásokat előállító termelési oldalára koncentrál, a vállalkozások ökológiai tudatosságát, mint a gazdaság fenntarthatóságát alapvetően befolyásoló tényezőt vizsgálja; a téma több tudományterületet (többek között etika, filozófia, környezettudomány, közgazdaságtan, pszichológia) átfogó jellemzői miatt interdiszciplináris módon. A téma terjedelme és az eltérő fókusz miatt a gazdaság keresleti oldalán jelentkező fenntartható, ökológiailag tudatos fogyasztás széles körü szakirodalmi hátterére azonban nem tér ki. A gazdaság kínálati és keresleti oldalán tapasztalható ökológiai tudatosság, illetve értékorientáció együttes vizsgálata azonban releváns jövőbeni kutatási irány, amely feltérképezéséhez a szerző a következő tanulmányokat emeli ki a teljesség igénye nélkül: a fenntartható fogyasztás trendjei, lehetőségei (Kerekes - Csutora, 2012), az ökologikus, fenntartható fogyasztás kapcsolata az értékekkel, illetve a tudatossággal (Brunsø et al., 2004; Csutora - Hofmeister-Tóth, 2011; Sudbury-Riley et al., 2014; Zsóka, 2007), a valódi ökológiai javuláshoz szükséges radikális életmódváltás (Sanne, 2002; Shove, 2004), a tudatosság, a környezetorientált viselkedés, a környezeti identitás, az értékek és a spiritualitás, valamint ökológiai hatásaik kapcsolata (Csutora, 2012; Csutora Zsóka, 2014; Kollmuss - Agyeman, 2002; Piskóti, 2015), az értékek, illetve különösen a környezeti értékek hatása a fogyasztói viselkedésre (Eibel-Spanyi - Hofmeister-Tóth, 2013; Fraj - Martinez, 2006), a fogyasztói értékek befolyása az ökológiai viszonyok romlására (Princen, 1977; Ahuvia - Wong, 2002).

\section{Az ökológiai tudatosság}

\section{Az ökológiai tudatosságtól az ökológiai közgazdaságtanig}

Az ökológiai tudatosság, mint jelenség eredete egészen az őskőkori vadászó-halászó-gyüjtögető társadalmakig vezethető vissza. A régészeti és összehasonlító néprajzi kutatások alátámasztják, hogy az emberi lélek „,természetes" állapotának pszichológiai mintái minden földrészen megközelítőleg azonosak voltak. Ezekben az ösi társadalmakban az ökológiai tudatosság magában foglalta az ,én”nek természettel való azonosulását és az élet tiszteletét. A világegyetemet szent létezőnek tekintették. Az ember a természet nagy egységének a része, függ tőle, nem pedig uralkodik rajta. Minden létező egy; az ember szoros kapcsolatban van minden élő és élettelen létezővel. Az ökológiai tudatosság megélése még a kezdeti mezőgazdasági társadalmakra, majd az első nagy civilizációk gondolatvilágára is jellemző volt. Az ókori görögöknél a püthagóreusok felfogása szerint az ember egy mikrokozmosz az univerzumon belül, teste ugyanazon elemekből épül fel, mint a világegyetem, lelke pedig annak lelkéből szárma- zik. Platón, illetve a sztoikusok is élő egésznek tekintették a kozmoszt a vele egy természetű élőlényekkel együtt. A világegyetem él, lélekkel és tudatossággal rendelkezik, amelyből az emberi lélek és értelem is származik. Keleten a hinduizmus és a taoizmus emberről szóló tanításai hasonlóak voltak (Hughes, 1991). Ahogy azonban az emberiség bioszféra-átalakító tevékenysége hat nagy ugrás (Takács-Sánta, 2004): a tűzhasználat, a nyelv megjelenése, a mezőgazdaság kialakulása, a civilizációk létrejötte, az európai hódítások és a technikai-tudományos-energetikai forradalom során egyre kiterjedtebbé vált, az ember fizikailag, pszichológiailag, spirituálisan fokozatosan elkülönült a nem emberi természettől. Az ökológiai tudatosság közösségi szinten meggyengült, a természeti környezet állapota pedig egyre inkább romlott (Hughes, 1991).

Az 1980-as évektől kezdve egyre növekvő érdeklődés mutatkozik az ökológiai tudatosság (ecological consciousness) iránt. A fogalmat az 1960-as évek végétől kezdték megkülönböztetni a környezeti tudatosságtól (environmental consciousness) olyan környezetvédő aktivisták és filozófusok, akik úgy gondolták, hogy a hagyományos természetvédő mozgalmak túl szüken értelmezik a környezeti problémákat. Az eleinte kevesek által vallott filozófiai nézőpont az évtizedek során a környezetvédő mozgalmak által elfogadott perspektívává vált, és mélyreható változásokat indított el a társadalomban, a kulturális, politikai és gazdasági intézményekben, az egyén, a társadalom és a természet fogalmának újradefiniálása által (Christopher, 1999).

Christopher (1999) megfogalmazásában az ökológiai tudatosság a környezeti problémák miatt érzett aggodalom, amelyet a természet degradációjáról szerzett tudás és tapasztalatok táplálnak. Az ökológiai tudatosság magában foglalja azt is, hogy a modern gondolkodás hibás ontológiai és episztemológiai előfeltevésekre épül, ami megakadályozza, hogy a mai ember helyesen fogja fel a környezeti problémákat, és megfelelöen tudjon válaszolni rájuk.

Az ökológiai gondolkodók szerint a hagyományos környezettudatosság technikai problémákká fokozza le a környezeti problémákat, ezáltal nem képes megérteni a kiváltó okaikat. A környezeti problémákat csak akkor lehet megoldani, ha a természet pusztulása miatti aggodalom mellé a természet, a társadalom és az egyén kapcsolatának ,ökológiai” megértése is társul (Christopher, 1999, p. 358.). Az ökológiai tudatosság központjában az a meggyőződés áll, hogy a környezeti problémák a modernitás társadalmi és kulturális intézményeiben (modern kapitalizmus, ipari technológia, individualizmus, mechanisztikus tudomány) megtestesülő instrumentális racionalitás elkerülhetetlen következményei, új racionalitásra épülő új társadalmi és kulturális intézmények nélkül a globális katasztrófa elkerülhetetlen (p. 361.). A fokozódó ökológiai fenyegetettség és aggodalom érzésén túl az ökológiai tudatosság azt is magában foglalja, hogy a racionalitás új metafizikai kereteit megfogalmazva, az egyén természetének és a világegyetemben elfoglalt helyének újfajta felfogásával adjunk értelmet a fenyegetésnek. E folyamat lépései az egyén atomisztikus koncepciójának felváltása holisztikus felfogással (a természet és az egyén ökoszisz- 
témák részei), az antropocentrizmusból kimenekítő, az új ontológiai keretekkel összhangban lévő etikai rendszer kialakítása, annak felismerése, hogy a kiterjesztett énfelfogás megvalósítása az egyén érzéseinek és világhoz való kapcsolatának változását magában foglaló pre-racionális folyamaton keresztül lehetséges, az előző lépéseket egyesítendő olyan ökológiai racionalitás keresése, amely járható utat teremt az ökológiai tudatosság kialakulását és erősítését támogató szociokulturális kapcsolatok újra racionalizálásához (p. 362-363.).

Az ökológiai tudatosság kialakulása Hamilton (2010) szerint is egy újfajta énérzet megjelenésétől és az embernek a természeti környezethez való új viszonyától függ. A gazdag és fogyasztásalapú társadalmak esetében azt kell megérteni, hogyan jön létre az emberek személyes identitása a fogyasztás és az azt kiszolgáló intézmények által, és hogyan cselekednek ezektől befolyásolva. A fogyasztók környezetpusztulással való szembesítése helyett hatékonyabb eszköz lehet, ha azzal állítjuk őket szembe, hogy az elérni szándékozott fogyasztói életmód valóban boldoggá teheti-e őket.

Az ökológiai tudatosság filozófiai és egyben cselekvő megközelítésének tekinthető az Arne Naess nevéhez kötődő mélyökológiai irányzat (Naess, 1989). Naess az általa „,sekély” ökológiának nevezett, a rövid távú problémákra koncentráló környezeti gondolkodást bírálja, mert az azt feltételezi, hogy a környezetszennyezés, az eröforrások kimerülése technológiai megoldásokkal orvosolható. Ezzel ellentétben Naess szerint mélyökológiára, a problémák gyökerének feltárására van szükség, és arra, hogy a fennálló redukcionista, antropocentrikus ideológiát, és benne az egyént, saját énképünket újrafogalmazzuk, gondolkodásmódunkat radikálisan megváltoztassuk. A számos kimagasló szellemi előd tanításaira (Arisztotelész, Buddha, Szent Ferenc, Spinoza, Thoreau, Aldo Leopold, Heidegger) épülő megközelítés olyan alapvető kérdésekre keresi a választ mint: Hogyan tudunk megbirkózni napjaink ideológiai küzdelmeivel? Mi az ember helye a természetben? Hogyan tudunk a jövő generációkról gondoskodni? A megoldást az ökológia alapelveit (összetettség, sokféleség, szimbiózis, egység) használó ökofilozófia pluralista nézőpontjától és az ökozófiának nevezett személyes megközelítéstől várja. Ezek alapján az ökológián és a gazdaságon, mint egyenrangú eszközökön alapuló személyes ökozófiákban minden embernek képesnek kell lennie kidolgozni teljes egyéni világképét, értékeit, normáit, és azok szerint cselekedni, felelősséget vállalni (Ims, 2015).

White (2011) az ökológiai tudatosság fogalmát a mélyökológiával és ökozófiával foglalkozó kutatók munkáiból eredezteti. A fogalommal az 1970-es évekbeni megjelenése óta - sokszor más megnevezést használva („ökológiai én”, „ideális létállapot”, „énmegvalósítás”, „ökológiai érzékenység”) - többen foglalkoztak (Beck, 1995, 1999; Bragg, 1996; Christopher, 1999; Devall, 1988; Devall - Sessions, 1985; Drengson, 1989, Hill et al., 2004; Leff, 1978; Milbraith, 1989; Morris, 2002; O’Sullivan Taylor, 2004; Uhl, 2004). Eredményeiket összefoglalva White a következő meghatározást adja: az ökológiai tudatosság az egyénnek a nem emberi természeti létezőkhöz füződő biológiai, ökológiai, érzelmi és spirituális kapcso- latairól való mély tudatosság, a nem emberi természettel való személyes azonosulás, a nem emberi természet önértékének tiszteletben tartása, mély aggodalom természeti környezetünk pusztítása miatt és ennek racionális megértéssel, aktív, érzelmi és pszicho-spirituális viszonyulással történő kezelése, az énmegvalósítás szándéka, amely magában foglalja a nem emberi létezők felé történő elköteleződést, annak megértése, hogy a globális környezeti válságot az uralkodó globális, ipari, fogyasztói modernitás és a természettől eltávolodott tudat okozza, késztetés a globális és személyes aggodalmak feldolgozására és az emberen túli fogalmak megértésére a természeti környezethez való tapasztalati és érzelmi kapcsolódás segítségével (White, 2011, p. 42.).

A közgazdaságtanon belül az ökológiai közgazdaságtan áll közel az ökológiai tudatosság kérdéséhez. A többek között Polányi Károly (2004), Herman Daly (Daly - Farley, 2004), Kenneth Boulding (1966), Robert Costanza (Costanza et al., 1997), Nicholas Georgescu-Roegen (2002) és Ernst F. Schumacher (1991) gondolatai által formálódott tudományterület karakteresen eltér a föáramú közgazdaságtan részét képező környezetgazdaságtantól. Az ökológiai közgazdaságtan felfogása szerint a gazdaság része az ökoszisztémáknak, nem pedig fordítva; a természeti tőke pedig nem helyettesíthető ember alkotta tőkével, mert a természeti változások jórészt visszafordíthatatlanok. Az ökológiai közgazdaságtanban hangsúlyos szerepet kap a holisztikus nézőpont, a generációk közötti méltányosság, a természeti folyamatok hosszú időtávja, a Föld eltartóképessége és a fenntartható fejlődés kérdése (Daly - Farley, 2004). Az ökológiai közgazdaságtannak Hans Jonas imperatívuszára támaszkodva kell megerősítenie az etikai hátterét. Ennek fó elemei, hogy az emberek tagjai és nem urai az élet közösségének a Földön, a Föld és élő rendszerei nem pusztán természeti erőforrások, hanem önmagukban is tiszteletre és törődésre méltó létezők, az életfeltételeket biztosító alacsony entrópiájú források és szennyezéselnyelö kapacitások gondos használatára és igazságos megosztására van szükség (Brown - Timmerman, 2015).

\section{Az ökológiai tudatosság etikai vonzatai}

Az elözőekben hivatkozott Aldo Leopold „Az ökológiai lelkiismeret" címü esszéjében ír arról, hogy a természet megőrzésének abból kell származnia, hogy mi helyes etikailag és esztétikailag, illetve célszerü gazdaságilag. Csak azok a dolgok tekinthetők helyesnek, amelyek megőrzik egy természeti közösség integritását, stabilitását és szépségét, ahol a közösségbe a talaj, a vizek, a flóra és a fauna is beleértendö.

Ha elfogadjuk az ökológiai lelkiismeret szükségességét, akkor a gazdasági nyereség nem lehet mentség az „antiszociális földhasználatra”, az ökológiai „rémtettekre". Pozitívan fogalmazva: a megfelelő földhasználatot annak társadalmi fontosságával arányos társadalmi jutalmakkal célszerü ösztönözni (Leopold, 1949). A megőrzés alapjának a föld-etikának (,lland ethics”) kell lennie, amely az embert az ökoszisztémák részeként fogja fel, az etika területét kiterjeszti a földre. Az újfajta ökológiai 
tudatosság azt jelenti, hogy az embernek a „föld-közösség” uralkodójából a többi fajjal egyenrangú polgárává kell válnia (Feng Lin - Fyles, 2015).

Thomas Merton, tapasztalva a XX. század gazdasági, ipari és katonai tevékenysége által okozott ökológiai pusztulást, valamint a vietnami háború természeti környezetben és emberéletekben óriási károkat okozó hatását, egyetértett Aldo Leopolddal, hogy az ökológiai lelkiismeret megerősítésére van szükség. E nélkül tovább folytatódik a természet és az ember könyörtelen és értelmetlen kizsákmányolása. A gazdaság és a háborúk okozta ökológiai tragédiák hátterében a modern nyugati ember közhelyekbe burkolt, a szabadság és a demokrácia védelmezőjének álcája mögé rejtőző agressziója, félelmei és uralkodási vágya húzódik meg. Mindezek pszichológiai gyökere az elembertelenedés és az elidegenedés. Az ember összetéveszti a tárgyak és az absztrakt dolgok (áruk, pénz, tulajdon) értékét az élettel magával, és az azonnali nyereséget mindennél többre tartja. Az ökológiai lelkiismeret megköveteli, hogy felismerjük a földi életközösség más tagjaival szembeni kötelezettségeinket, és az élet minden formáját tiszteljük (Merton, 1968).

Az ökológiai tudatosság meghatározó képviselője James Lovelock az angol geokémikus-ökológus, aki - az emberi tevékenység által kiváltott globális ökológiai változások kutatásai, illetve az 1960-as években elindult marsi életet vizsgáló program tapasztalatai alapján - az amerikai biológus Lynn Margulis-szal közösen dolgozta ki az ún. Gaia-elméletet. E szerint az elmélet szerint a földi élő és élettelen rendszerek szorosan összefüggenek, és önszabályozó (homeosztatikus) rendszert alkotnak. A görög mitológia Föld istennője (az anyatermészet, az anyaföld) után elnevezett „Gaia” a Föld bioszféráját, atmoszféráját, vizeit és földjeit magában foglaló komplex, önszabályozó rendszer, amely optimális fizikai-kémiai környezetet biztosít a földi élet számára (Lovelock, 2010). Ennek fényében a Gaia-etika azt követeli meg, hogy a gazdasági tevékenységek ne sértsék ,a Föld globális mintázatainak és mechanizmusainak az épségét, integritását" (tartózkodás a fajok kiirtásától, üvegházhatású gázok kibocsátásától, globális felmelegedést kiváltó széndioxid-kibocsátástól) (Zsolnai, 2001).

Bandura (2007) szerint, ha valóban a természet felelős gondnokai akarunk lenni, és azt meg kívánjuk örizni a jövő generációk számára, akkor meg kell nehezíteni a morális önfelmentési stratégiák alkalmazását (moral disengagement) az ökológiailag romboló tevékenységek elkövetői számára. A természetkárosító gyakorlatok lelkiismereti kérdéseit az ember ugyanis pszichés stratégiák segítségével eltávolítja magától, hogy továbbra is fenntarthassa addigi tevékenységét, és ne kelljen szembenéznie annak negatív következményeivel. A globális méretü ökológiai és emberi károkat (erdőirtás, elsivatagosodás, globális felmelegedés, jégtakaró olvadása, tengerszint-emelkedés, szélsőséges időjárási viszonyok, talajpusztulás, a biológiai sokféleség csökkenése) okozó tevékenységeket sokszor valamely magasabb társadalmi, nemzeti vagy gazdasági célra hivatkozva próbálják igazolni, kedvező összehasonlításokkal bizonyítják a saját gyakorlatuk elfogadhatóságát, megszépítő nyelvezet mögé rejtik a valódi történéseket, a felelősség elhárításá- val és szétterítésével csökkentik az elszámoltathatóságot; figyelmen kívül hagyják, minimalizálják vagy vitatják az általuk okozott káros hatásokat, dehumanizálják és hibáztatják az áldozatokat és elhiteltelenítik a kedvezőtlen hírek közlöit. E pszichoszociális mechanizmusok egyéni és társadalmi szinten is müködnek, ezért különösen fontos, hogy mielöbb csökkentsük, megállítsuk a természeti környezet és a jövő megőrzését gátló tényezőket, illetve aktivizáljuk ökológiai lelkiismeretünket.

Hans Jonas az emberi tevékenység természetének, térbeli és időbeli hatókörének, kiterjedésének drámai változását tapasztalva hívta fel a figyelmet egy újfajta etika szükségességére, a felelősség elvének fontosságára. Az ember összeadódó és visszafordíthatatlan károkat okoz az élő természetben, ezért etikai követelmény a gondoskodás, a felelős viselkedés az önértékkel rendelkező természeti létezőkkel szemben. Úgy kell élnünk és cselekednünk, hogy ne veszélyeztessük az élet jövőbeni fennmaradását a Földön. Emberi kötelesség a jövő generációk és a természet iránti nem viszonosságon alapuló, gondoskodói hozzáállás vállalása. A jövő generációk és a természeti létezők életfeltételeinek megőrzésére irányuló emberi felelősség szubsztantív jellegü (Jonas, 1984; Zsolnai, 2014a). A gazdasági döntéshozók természetes és szerződéses felelősséggel is rendelkeznek az érintettjeik irányában attól függően, hogy az adott érintettekkel szerződéses (szállítók, alkalmazottak, fogyasztók) vagy természetes módon (helyi közösségek, természeti környezet, jövő generációk) állnak kapcsolatban (Zsolnai, 2000).

Gregory Bateson széles körü antropológiai, biológiai, nyelvészeti, pszichológiai, kibernetikai, ökológiai és filozófiai kutatásai alapján jutott arra a következtetésre, hogy a modern filozófiai és tudományos gondolkodásban megtalálható dualitás (elme - test, ember - természet, társadalom - ökológia, biológiai - érzelmi, Isten - természet) alapvetően hamis. A világ egyéneket, társadalmakat és ökoszisztémákat magában foglaló rendszerekből épül fel, amelyek részei egy magasabb szintü, átfogó rendszernek. Ezt sokan Istennek, Bateson pedig „Mind”-nak nevezi. A tudatosság a híd az egyén, a társadalom és az ökológia között, a nyugati episztemológián keresztül fejlődött korlátozott tudatosság azonban nem összeegyeztethető az Univerzális Elmével. Ennek oka, hogy a nyugati gondolkodás túlságosan célorientált, így leszükíti a figyelmet, az érzékelést, a tudatosság befogadóképességét. Azt a téves elképzelést erősíti, hogy az ember képes minden rendszert uralni, így a saját igényeinek megfelelöen átalakíthatja azokat felbillentve a természetes egyensúlyt, tönkretéve az önjavító mechanizmusokat. Bateson megoldásként az alázatot és a természetes kibernetikus (önvezérelt) rendszerek elfogadását javasolja. A gondolkodást, a kizárólag kognitív alapú megismerést egészítsük ki az érzelmeket és a tudatalatti tényezőket is szintetizáló teljesebb tudatossággá. Mindezek eléréséhez a következő tényezők szükségesek: a szeretet kiterjesztése az egyének szintjéről a társadalmak, ökoszisztémák felé, a müvészetek, költészet, zene gyakorlása az elme befogadóképességének tágításához, kapcsolat ember és állat, ember és természet között, illetve a vallásgyakorlás/spiritualitás. Az emberi civilizáció elérendő egészséges ökológiája a természet és 
az emberi civilizáció egységes rendszere, amelyben a civilizáció rugalmassága megegyezik a természetével, és nyitott még az alapjellemzőinek lassú változására is (Bateson, 1972).

\section{Ökológiai tudatosság és spiritualitás}

White-nál és Batesonnál is láttuk, hogyan jelenik meg a spiritualitás az ökológiai tudatosság vizsgálatakor. Most tekintsük át az ökológiai tudatosság témáját a spiritualitásra fókuszálva.

\section{A spiritualitás fogalma}

A profitmaximalizálásra összpontosító modern gazdasági működés veszélyezteti a természeti ökoszisztémák integritását, sokféleségét, a helyi közösségek autonómiáját, kultúráját és a jövő generációk életfeltételeit. A természet megörzéséhez és a valódi emberi szükségletek kielégítéséhez mértékletes és gondos gazdálkodásra van szükség. Ez megköveteli a gazdasági szereplők arra irányuló belső motivációját, hogy a közjót szolgálják, és hogy a pénzen kívül más értékkategóriákban is mérjék a sikerességüket. Ennek alapja a spiritualitás lehet, mert e nélkül az etikus üzleti kezdeményezések, környezetvédelmi intézkedések hatástalanokká válhatnak, és a kívánatossal éppen ellentétes eredményre vezethetnek (Zsolnai, 2015b).

Az emberi közösségek, a természeti ökoszisztémák és a jövő generációk jóllétéhez tehát elkötelezett, valódi gondosságra van szükség, ami a többi létezővel és a teremtés egyetemes forrásával való egység megtapasztalásából származhat. A spirituális tapasztalatoknak kiemelkedö szerepük van a döntéshozók személyiségének és etikus viselkedésének a fejlődésében, továbbá hozzájárulnak ahhoz, hogy a vezetők mélyebben megértsék a különböző döntési helyzeteket, rendszereket, új kategóriákat legyenek képesek alkotni, és a fennálló paradigmákon túlléphessenek (Zsolnai, 2014b). A spiritualitás fogalma sokáig kizárólag a vallásokhoz kapcsolódott, de ma már egyértelmüen meghaladja az intézményesült vallások kereteit. A következő fő összetevőkből áll: kapcsolódás a belső ,én”-hez; az egyént az önközpontú törekvések fölé emelő egyetemes értékek keresése, minden élővel való mély együttérzés, az élet forrásával való kapcsolatteremtés (Bouckaert - Zsolnai, 2012). A European SPES Institute (2017) meghatározása szerint a spiritualitás az élet értelmének - különböző szociokulturális formákban való - keresése, amely összeköti az embereket minden élővel és Istennel, avagy a Végső Valósággal.

\section{A spiritualitásalapú vezetés}

A spiritualitás egy gazdasági alkalmazási koncepciója a spiritualitásalapú vezetés, amelyben a megélt spiritualitásuk a vezetőket belső forrásként irányítja, miközben értelmet, célt és kiteljesedést keresnek a külső üzleti világban és tudatosságuk, lelkiismeretük belső világában egyaránt. Külső tetteik és belső reflexióik egymást támogatják, azaz a racionalitás és a spiritualitás egymást segítő nézőponttá válik a számukra (Pruzan, 2011). Mindezek eléréséhez azonban nem elég a vezetők képzését és a vezetés gyakorlatát átalakítani, az egyes vezetők gondolkodásmódjának, tudatosságának változása, a belső irányítás és lelkiismeret megerősítése is szükséges (Pruzan, 2015a). A lét lényegének megismerése, a valódi Én megtapasztalása minden vezető számára elérhető. Ez azután a vezető döntéseiben, a külső üzleti világban is tükröződik majd. A spiritualitásalapú vezetés koncepciójának és gyakorlatának elfogadása, fejlesztése és támogatása azonban mindenek előtt attól függ, hogy a vezetők mennyire válnak tudatossá saját spiritualitásukról, a velük született isteniről, tökéletességről (Pruzan, 2015b).

\section{Ökológiai tudatosság és vallás}

Hogyan jelennek meg korunk három meghatározó világnézeti rendszerében (katolikus kereszténység, Gandhi filozófiája, buddhista közgazdaságtan) az ökológiai tudatosság szempontjai?

Ferenc pápa - az ökológia védőszentjévé választott Assisi Szent Ferenc tanításai által inspirált - „Áldott légy” (Laudato si') kezdetü enciklikája mutatja be a katolikus egyház ökológiai álláspontját. Ferenc pápa az ökológiai válság kérdéseinek fontosságára hívja fel a figyelmet, és összeköti azokat a társadalmi igazságosság kihívásaival. Tudományos pontossággal mutatja be a mai kor ökológiai és társadalmi válságtüneteit (környezetszennyezés, klímaváltozás, ivóvízszükösség, a biológiai sokféleség csökkenése, az emberi életminőség és a társadalmak leromlása, globális egyenlőtlenségek), és megoldásként Assisi Szent Ferenc életét és tanítását állítja elénk. A kiszolgáltatott emberek és természeti létezők iránti törődés, a béke, az öröm, az önzetlenség és a nyitottság érzése önmagunkban és a világ felé, a szellemi gazdagságot lehetővé tevő anyagi lemondás a legfontosabb alapjai az ,integrál ökológiá"-nak nevezett, az emberekre és a természetre egyaránt odafigyelö, a humánus értékekkel telített transzdiszciplináris hozzáállásnak. Az ökológiának és a gazdaságnak, a természet- és társadalomtudományoknak, müvészeteknek, oktatásnak együtt kell müködniük, hogy a haszonelvü (individualista, végtelen növekedést feltételező, versenyre, fogyasztásra és szabályozatlan piacra épülő) modern gondolkodást felválthassa a méltányosságon, az igazságosságon, a mértékletes fogyasztáson, a természet önértékének elismerésén és a holisztikus világszemléleten alapuló „ökológiai polgárság” (ecological citizenship) eszménye. Az egyéni és közösségi ökológiai átalakulás alapja az ökológiai spiritualitás lehet, amelyben az ember a nagylelkű gondoskodás, az érzékenység, a hála érzése és az önfeláldozó munka által felismeri, hogy nem különül el a világtól, hanem egyetemes közösségben él az összes többi teremtménnyel (Ferenc pápa, 2015).

Gandhi filozófiájának alapjait a hinduizmus, a dzsainizmus és a buddhizmus, illetve John Ruskin „Unto This Last" című művének tanításai jelentették. A nem-ártás (,ahimsa”) ősi védikus elve vált a hitvallásává. Fontos inspirációt jelentett számára továbbá Assisi Szent Ferenc a természettel való alázatos, békés és együttérző kapcsolat, az egyszerűség és az önkéntes, méltóságteljes szegénység gyakorlásában. A nem-ártás a létezés végső valóságát jelentő Igazság elérésének központi eleme volt számára, amiben személyes példát mutatott, amikor politikai céljait 
nem erőszakkal, hanem az elnyomó hatalommal szembeni passzív ellenállással valósította meg. A nem-ártást alkalmazta életének, munkájának minden szegmensében, politikában, gazdasági, vallási, etikai, ökológiai kérdésekben. Legfőbb célja az indiai szegények nehézségeinek az enyhítése volt, amit az alapvető emberi szükségletek kielégítésére helyi szinten törekvő önellátó, kisléptékü, decentralizált, ökológiailag fenntartható gazdaságok segítségével tervezett elérni. Nem volt a gazdasági fejlödés, a tőke, a gépek vagy a piac ellensége, de a korlátlan iparosítást, a profittermelő vállalatokat és az erőforrások piaci elosztását ellenezte (Kovács - Ócsai, 2015). Ökológiai nézetei is a nem-ártáson alapultak: azt vallotta, hogy az állatoknak is vannak jogai, hogy életünk célját, önmagunk megismerését csak akkor tudjuk elérni, ha minden létezővel egynek tekintjük magunkat, és az önzetlen szolgálat vezet el annak felismeréséhez, hogy Isten minden létezőben ott van (Timmerman, 2015).

Gandhi felfogása nagy befolyást gyakorolt Ernst Friedrich Schumacherre, aki az 1970-es években alakította ki a buddhista közgazdaságtan koncepcióját (Kovács - Ócsai, 2015). A buddhizmus legkorábbi tanításai nem foglalkoznak külön a természettel, mert az i. e. V. század körül még nem volt probléma a környezetszennyezés. A fö kérdés az emberi szenvedés megszüntetése volt. A buddhista környezeti attitüd azonban mégis ökologikusnak tekinthetö, mert olyan környezeti erények (nem-ártás, együttérzés, a kis lépték szeretete, a hála, a megelégedés, az egyszerüség, a bölcsesség és a tudatosság) fejlődnek ki, amik érzékennyé tesznek a természeti gondok iránt. A buddhista életmód és stratégia legfóbb célja a szenvedés megszüntetése, ami a Nemes Nyolcrétü Ösvény követésén keresztül érhető el (Kovács, 2015). Ez viszont ellentétben áll a modern nyugati közgazdaságtan alapelveivel (profitmaximalizálás, a vágyak kielégítése, piacok bevezetése, a világ instrumentális használata, önérdekre épülő etika). A buddhista közgazdaságtan fö elemei a szenvedés minimalizálása, a vágyak egyszerüsítése, a nem-ártás gyakorlása, a valódi gondoskodás és a nagylelkűség, amelyek segítségével a termelés és a fogyasztás az ökológiai fenntarthatóság irányába mozdítható el (Zsolnai, 2014c).

\section{Vállalkozások ökológiai tudatossága}

Brenkert (1995) szerint az üzleti világ speciális „etikával” rendelkezik, amely a szabad piaci rendszerrel és a gazdasági társaságok természetével függ össze. Ez alapján a gazdaság nem képes környezetileg felelösen müködni, mert a társadalom, a kormányzat szabta kereteken belül elsődleges célja a nyereség maximalizálása. Ez a vállalatok „,közgazdasági modellje”, amellyel szemben a „moralista modell" szerint a vállalkozások morális cselekvők, akiknek a törvények betartásán túl erkölcsileg helyesen, társadalmilag és környezetileg felelösen kell tevékenykedniük, azaz minimalizálni a károkozást és megoldani a környezeti problémákat. Mindehhez a vállalatoknak biocentrikus környezeti etikát kellene követniük (Hoffman, 1991 idézi Brenkert, 1995), valamint az egyes vállalatok környezeti lelkiismeretéből kifejlődő globális tudatos- ságra lenne szükség (Goodpaster, 1990 idézi Brenkert, 1995). A gazdaság és a vállalatok belső törvényszerüségei (a szabad piaci vállalkozáshoz szükséges attitűdök, értékek, bürokratikus üzleti struktúrák, a rövid távú profitérdekeltség, növekedéskényszer, erőforráskihasználás, specializáció, árverseny) azonban megnehezítik, hogy a gazdasági szereplők valóban morálisan viselkedhessenek, morális tudatosságuk széttöredezik. Alapvető változásra van tehát szükség a gazdasági rendszerben és a gazdasági társaságokban (elszámoltathatóság erősítése, a racionalitás kibővítése, demokratizálás, nyitottság, környezetvédelem, fenntartható fejlődés), hogy a vállalatok és dolgozóik morálisan cselekedhessenek, a környezeti felelösségvállalásuk erősödhessen (Brenkert, 1995).

A környezeti problémáknál az indusztriális és az ökológiai világszemlélet élesen különbözik egymástól. Timothy O’Riordan megfogalmazásában az ökológiai világszemlélet esetén a cél a harmónia a természettel. A természet nem csupán erőforrás, hiszen minden faj egyenlö, minden természeti létező önértékkel rendelkezik. A Föld erőforrásai végesek, amelyek a gazdasági növekedés elé korlátokat állítanak. A tudomány és a technológiai fejlődés nem tud mindent megoldani, a technológiának alkalmazkodnia kell a természethez és az emberhez. A fogyasztói vágyak korlátlan kielégítése helyett a szükségletekre kell helyezni a hangsúlyt, az emberek tudatosan egyszerü életmód keretében fogyasztói igényeiket képesek és hajlandóak kontrollálni. A hatalom elosztása decentralizált, és figyelembe veszi a természet és az emberek jogait (O’Riordan - Cameron, 1994 idézi Zsolnai, 2001).

Milyen következményeket von ez a világszemlélet maga után az ökológiailag tudatos vagy arra törekvő vállalkozások esetében?

\section{Vállalkozások és fenntarthatóság}

Számos kutatás foglalkozik azzal, hogy a vállalkozásoknak az ökológiai és társadalmi folyamatok pusztítása helyett minél inkább támogatniuk kellene azokat. E kutatások nagy része azonban önérdekkövetőnek és profitmaximalizálónak tekinti a gazdasági szereplőket, és a meglévő üzleti stratégiákba igyekszik beépíteni a fenntartható fejlödés elveit. Parrish (2010) kitágítja ezt a szük keretet, és a nézőpont megfordításával arra keresi a választ, hogy a fenntarthatósági értékekkel és motivációkkal rendelkező vállalkozók milyen szervezeti tényezők segítségével tudnák értékeiket a leghatékonyabban megvalósítani a versenypiaci körülmények között. Parrish négy különböző szektorban és földrészen müködö, eltérő mérettel és üzleti modellel rendelkező sikeres fenntartható vállalkozás esettanulmányának kvalitatív elemzésén keresztül öt kategóriában mutatja be sajátosságaikat a konvencionális vállalkozókhoz képest ((1) céljuk, létezésük indoka: az emberi és természeti erőforrások minőségének lehető leghosszabb időtávon történő megőrzése és erősítése, (2) hatékonyság, szinergiák: az elért hasznok növelése minden tevékenységnél a költséghatékonyság üldözése helyett, (3) tradeoffok, célok közötti egyensúly: egyszerre több cél kielégítő eredményének azonosítása, nem csupán egy dimenzió értékének maximalizálása, (4) döntési kritérium, 
prioritás: az eredmények várható minősége, (5) hasznok elosztása: az elért érdemek és nem hatalmi viszonyok alapján (Parrish, 2010, p. 517.)). A fenntarthatóság által vezérelt vállalkozások által követett értékek kiegyensúlyozottságot teremtenek az egyén, a többi ember és a természet között, de a szervezetben feszültségeket okozhatnak. A sikeres vállalkozókat az különbözteti meg a többiektől, hogy megfelelő értékorientáció mellett a felmerülő szervezeti feszültségeket a fenti szempontok sikeres gyakorlati alkalmazásával oldják meg.

Dyllick és Muff (2015) szerint a fenntarthatósági menedzsment (sustainability management) egyre elterjedtebb a nagy vállalatok körében, de az ez irányú törekvések hatása nem jelentkezik bolygónk ökológiai állapotának javulásában. A mikroszintű fejlődés és a makroszintű romlás közötti „nagy szétkapcsolódás” (big disconnect) okait keresve megvizsgálták az üzleti fenntarthatóság (business sustainability) elméleti és gyakorlati hátterét, és egy négy fokozatú tipológiát dolgoztak ki az üzleti modellek fenntarthatóságának elemzéséhez. A kiinduló szint a napjainkban uralkodó üzleti hozzáállás, a ,business-as-usual" Milton Friedman-i felfogása. Ezt a finomított tulajdonosi értékteremtés (refined shareholder value management) modelljei követik, amelyek kizárólag a gazdasági kockázatot vagy lehetőséget jelentő ökológiai, társadalmi kérdésekkel foglalkoznak, de alapvetö üzleti stratégiájuk megváltoztatása nélkül. A harmadik szinten azok az üzleti modellek találhatók, amelyek a gazdasági, társadalmi és környezeti értékeket egyaránt szem előtt tartják müködésük során (triple bottom line koncepció). A legmagasabb szinten a fenntarthatóság szempontjából leghaladóbb üzleti modellek (truly sustainable business) nézőpontjukat a negatív hatásokat minimalizáló törekvésektől kiterjesztik annak megértése felé, hogy miként tudnának minél nagyobb pozitív hatást gyakorolni a kritikus társadalmi és ökológiai kérdésekben. A legégetőbb fenntarthatósági kihívások megoldását formálják üzleti lehetőségekké. Hatásukat nem csak a vállalatuk szintjén igyekeznek kifejteni, hanem egész szektorukban, illetve más szektorok felé is. Ennek eszköze átláthatóságuk növelése, jó gyakorlataik megosztása, közös önszabályozás és szabványok meghatározása, együttműködések kiépítése a gazdaságon kívüli szereplőkkel, továbbá a játékszabályok megváltoztatására törekvés. A szerzők elismerik, hogy ez a nézőpontváltás óriási kihívás, a jelenlegitől alapvetően különböző stratégiai hozzáállást követel meg a gazdálkodó szervezetektől, és számos nagyon erős akadályozó tényező (a pénzügyi piacok erős részvényesiérték-orientációja, rövid távú megtérülési igény) nehezíti a megvalósítását. Azzal azonban nem foglalkoznak, hogy a legmagasabb szintű fenntarthatóság felé való elmozduláshoz pontosan milyen változások szükségesek az uralkodó gazdasági modellben, és ezek hogyan valósíthatók meg.

\section{Természet által ihletett vállalkozások, környezeti felelősségvállalás}

A modern társadalmak gazdasági vállalkozásainak többsége kizsákmányolja a természetet és tönkreteszi az ökoszisztémákat, mert egyszerü nyersanyagforrásként tekint rájuk. A tökét és a munkaeröt fontosabb termelési tényezőnek tartják a természetnél, így az üzleti stratégiákat is azokra építik. A természet által inspirált, fenntartható vállalkozások azonban más világszemlélettel rendelkeznek, és olyan megújító termék- és szolgáltatásinnovációkat hajtanak végre, amelyek regenerálják a természeti szolgáltatásokat, újra összekötik az embert a természettel (regenerative eco-innovations). E világnézetnek az alapja egyfajta környezeti bölcsesség, amely felismeri, hogy az ember a természet része, függ tőle. A természet az összes fajért létezik, ezért a korlátozott erőforrásokat nem szabad csak saját emberi igényeink kielégítésére használni. Csak a Földet fenntartó gazdaság engedhető meg, és sikerességünk attól függ, hogy mennyire leszünk képesek tanulni a természet önfenntartó folyamataiból. A fenntartható vállalkozásoknak ökohatékonyaknak kell lenniük: valós ökológiai problémákat megoldani, párhuzamosan az emberi szükségletek kielégítésével és gazdasági érték termelésével, illetve ökohatásosnak, azaz olyan termékeket és szolgáltatások előállítani, amelyek ténylegesen kiszolgálják az emberi és természeti igényeket és javítják az életminőséget.

Ahhoz, hogy egy természet által inspirált vállalkozó sikeres lehessen, öt alapelvet kell figyelembe vennie:

- a természeti erőforrások által okozott nem várt fenyegetések előrejelzése, átalakítása üzleti lehetőségekké, a természet szerepét tanítóként, mentorként felfogva,

- a gazdaság, a társadalom és a természet különböző érdekeinek figyelembevétele,

- hosszú távú gazdasági hatékonyság elérése, etikai nézőpontok és ökológiai hatásosság megvalósításával,

- a természet felfedezése és nem kizsákmányolása,

- tág értelemben vett üzleti érték előállítása, amely a gazdasági, ökológiai, erkölcsi, társadalmi és spirituális értékeket is magában foglalja (Hofstra, 2015).

A napjainkra kialakult helyzetben környezeti szempontból biztonságot csak új vállalati etikai felfogás, társadalmi és környezeti felelősségvállalás (környezetvédelmi elvárások teljesítése állami szabályozás, normák hiányában is) jelenthet. A vállalkozások társadalmi, környezeti kérdések iránti elkötelezettsége az elöírások teljesítésétől, a veszélyek minimalizálásán át az értékteremtés irányába fejlődik. A környezeti elköteleződés alapjai lehetnek társadalmi normák (például érintettek elvárásai, állami szabályozások), technológiai lehetőségek (sikeres innovációk, ellátási láncon belüli kapcsolatok természete), valamint a vállalatvezetők kognitív, magatartási jellemzői (például környezeti elkötelezettség, morál, előfeltevések) (Csutora - Kerekes, 2004; Kerekes - Wetzker, 2007).

A természeti erőforrások megőrzését, a szennyezések és kockázatok csökkentését célzó környezettudatos vállalatirányításhoz (environmental management) és a vállalatok társadalmi felelősségéhez (corporate social responsibility) kapcsolódó eszközök (többek között a tisztább termelés, energiaracionalizálás, ökohatékonyság, környezetbarát ter- 
mékek, termékéletciklus-elemzés, környezeti termékcímkézés és teljesítményértékelés, környezeti jelentések, ipari ökológia, ökológiai könyvvitel, környezetközpontú irányítási rendszerek, illetve etikai kódexek, vállalatirányítási szabványok, fenntarthatósági jelentések, terméktanúsítványok, társadalmilag felelős befektetések) alkalmazása Tóth (2007) szerint operatív megközelítésnek tekinthető, amely szükséges, de nem elégséges a fenntartható fejlődés eléréséhez. E cél a gazdaság, az emberiség egésze szempontjából stratégiai kérdés, korunk legnagyobb kihívása, amely megoldásához a szerző a „Valóban Felelős Vállalat” koncepcióját javasolja. Ennek öt alapelve (1) a szállítás minimalizálása és helyi piacok előnyben részesítése, (2) az igazságosság, a méltányos- ság erősítése, (3) a túlzott mértékü nyereségnövelés kerülése, (4) az optimális méret elérése és megőrzése, valamint (5) a valódi szükségletek kielégítő termékek. Az ilyen vállalkozások piramisszerüen egymásra épülő kategóriák mentén változhatnak, fejlődhetnek a ,rendes, helyi vállalkozásoktól” indulva az ,értékalapú szervezeteken”, illetve „másért vállalkozókon” keresztül a „,közösséget szolgáló vállalatok” felé (Tóth, 2007, p. 88-91.). Fontos még, hogy e radikális változások megvalósításához a felelősséget személyek (vállalatvezetők, tulajdonosok) tudják vállalni, és akár alaptermékeik, stratégiájuk teljes átdolgozására, új vállalkozások alapítására lehet, illetve sokkal több tényleges cselekvésre, mint arról való kommunikációra van szükség. (1. táblázat)

1. táblázat

A vállalkozások ökológiai tudatosságával foglalkozó szakirodalmi áttekintés főbb megállapításai

\begin{tabular}{|c|c|c|c|}
\hline Fejezet / Alfejezet & Koncepció & Forrás & Főbb megállapítások \\
\hline \multirow{6}{*}{$\begin{array}{l}\text { Ökológiai } \\
\text { tudatosság / } \\
\text { Az ökológiai } \\
\text { tudatosságtól az } \\
\text { ökológiai közgaz- } \\
\text { daságtanig }\end{array}$} & \multirow{4}{*}{$\begin{array}{c}\text { ökológiai } \\
\text { tudatosság }\end{array}$} & Hughes (1991) & $\begin{array}{l}\text { eredete az őskőkori társadalmakig nyúlik vissza; } \\
\text { emberi lélek „természetes” állapota; az „én” természettel való azonosulása; szoros } \\
\text { kapcsolat minden létezővel; } \\
\text { jellemző még első nagy civilizációknál, majd fizikai, pszichológiai, spirituális elkü- } \\
\text { lönülés a nem emberi természettől és a természeti környezet állapotának fokozatos } \\
\text { romlása }\end{array}$ \\
\hline & & Christopher (1999) & $\begin{array}{l}\text { 1960-as évektől megkülönböztetik környezeti tudatosságtól, 1980-as évektől növek- } \\
\text { vő érdeklődés; } \\
\text { környezeti problémák miatt érzett aggodalom és meggyőződés, hogy a környezeti } \\
\text { problémák a modern társadalmi, kulturális intézményekben (modern kapitalizmus, } \\
\text { ipari technológia, individualizmus, mechanisztikus tudomány) megtestesülő instru- } \\
\text { mentális racionalitás következményei; } \\
\text { a megoldáshoz új intézmények, új, ökológiai racionalitás, az egyén világegyetemben } \\
\text { elfoglalt helyének újfajta felfogása szükséges (atomisztikus helyett holisztikus) }\end{array}$ \\
\hline & & Hamilton (2010) & $\begin{array}{l}\text { kialakulásához újfajta énérzet, az ember természeti környezethez való új viszonya } \\
\text { szükséges; } \\
\text { meg kell érteni, hogy a fogyasztásalapú társadalmakban hogyan jön létre az emberek } \\
\text { személyes identitása a fogyasztás intézményei által; } \\
\text { fogyasztók szembesítése elérni szándékozott életmód hatásaival, következményeivel }\end{array}$ \\
\hline & & White (2011) & $\begin{array}{l}\text { 1970-es évek óta kutatják, többféle elnevezéssel (ökológiai én, ideális létállapot, } \\
\text { én-megvalósítás, ökológiai érzékenység); } \\
\text { meghatározásához mélyökológiai, ökozófiai előzmények összefoglalása: mély tuda- } \\
\text { tosság az egyénnek a nem emberi természeti létezőkhöz füződő biológiai, ökológiai, } \\
\text { érzelmi és spirituális kapcsolatairól; a nem emberi természet önértékének tisztelete; } \\
\text { mély aggodalom a természet pusztítása miatt és ennek racionális megértéssel, aktív, } \\
\text { érzelmi, pszicho-spirituális viszonyulással történő kezelése; késztetés az emberen } \\
\text { túli fogalmak megértésére a természethez való tapasztalati, érzelmi kapcsolódás által }\end{array}$ \\
\hline & $\begin{array}{c}\text { mélyökológia, } \\
\text { ökozófia }\end{array}$ & \begin{tabular}{|l|} 
Naess (1989) és Leff \\
(1978), Devall - Ses- \\
sions (1985), Devall \\
(1988), Drengson \\
(1989), Milbraith \\
(1989), Beck (1995, \\
1999), Bragg (1996), \\
Morris (2002), Hill et \\
al. (2004), O’Sullivan \\
- Taylor (2004), Uhl \\
(2004), Ims (2015) \\
\end{tabular} & $\begin{array}{l}\text { filozófiai és egyben cselekvö megközelítés; } \\
\text { a rövid távú problémákra koncentráló, a környezetszennyezést, az erőforrások ki- } \\
\text { merülését technológiai megoldásokkal orvosolhatónak tartó környezeti gondolkodás } \\
\text { (,,sekély” ökológia) helyett a problémák gyökerének feltárására, a fennálló redukcio- } \\
\text { nista, antropocentrikus ideológia, az egyén énképének újrafogalmazására, a gondol- } \\
\text { kodásmód radikális megváltoztatására van szükség; } \\
\text { a megoldás a pluralista ökofilozófián (alapértékei: összetettség, sokféleség, szimbió- } \\
\text { zis, egység) és az ökozófiának nevezett személyes megközelítésen alapul. } \\
\text { Az ökozófiában az ökológia és a gazdaság egyenrangú, és minden ember képes } \\
\text { meghatározni világképét, értékeit, és azok szerint cselekedni, felelősséget vállalni }\end{array}$ \\
\hline & $\begin{array}{c}\text { ökológiai } \\
\text { közgazdaságtan }\end{array}$ & $\begin{array}{l}\text { Polányi (2004 } \\
\text { [1944]), Boulding } \\
(1966), \text { Schumacher } \\
(1991), \text { Costanza } \\
(1997), \text { Georges- } \\
\text { cu-Roegen (2002), } \\
\text { Daly - Farley (2004), } \\
\text { Brown - Timmer- } \\
\text { man (2015) }\end{array}$ & $\begin{array}{l}\text { határozottan eltér a főáramú közgazdaságtan részét képező környezetgazdaságtantól; } \\
\text { felfogása szerint a gazdaság része az ökoszisztémáknak, nem fordítva; a természeti } \\
\text { tőke nem helyettesíthető ember alkotta tökével, mert a természeti változások jórészt } \\
\text { visszafordíthatatlanok; } \\
\text { kiemelten fontos a holisztikus nézőpont, a generációk közötti méltányosság, a ter- } \\
\text { mészeti folyamatok hosszú időtávja, a Föld eltartóképessége, a fenntartható fejlődés } \\
\text { kérdése; } \\
\text { etikai háttere: az ember nem ura, hanem tagja a földi életközösségnek, a Föld élő } \\
\text { rendszereinek önértéke van, nem pusztán eröforrások, életfeltételeket biztosító szol- } \\
\text { gáltatásaik gondos használatára és igazságos elosztására van szükség }\end{array}$ \\
\hline
\end{tabular}




\begin{tabular}{|c|c|c|c|}
\hline \multirow{5}{*}{$\begin{array}{l}\text { Ökológiai } \\
\text { tudatosság / } \\
\text { Az ökológiai tu- } \\
\text { datosság etikai } \\
\text { vonzatai }\end{array}$} & $\begin{array}{c}\text { ökológiai } \\
\text { lelkiismeret, } \\
\text { föld-etika (land } \\
\text { ethics) }\end{array}$ & $\begin{array}{l}\text { Leopold (1949), } \\
\text { Merton (1968), Feng } \\
\text { Lin - Fyles (2015) }\end{array}$ & $\begin{array}{l}\text { a természet megőrzésének etikai, esztétikai értékeken és gazdasági célszerüségen } \\
\text { kell alapulnia; az a dolog helyes, ami megörzi a természet integritását, stabilitását, } \\
\text { szépségét; } \\
\text { a megörzés alapja a föld-etika, amely szerint az ember az ökoszisztémák része, és a } \\
\text { „föld-közösség” uralkodójából a többi fajjal egyenrangú polgárává kell válnia; } \\
\text { az ökológiai lelkiismeret megerősítése, az élet minden formájának tisztelete nélkül } \\
\text { tovább folytatódik a természet és az ember - a modern nyugati ember agressziója, } \\
\text { félelmei, uralkodási vágya, illetve az elembertelenedés, elidegenedés okozta - ki- } \\
\text { zsákmányolása }\end{array}$ \\
\hline & $\begin{array}{l}\text { Gaia-elmélet, } \\
\text { Gaia-etika }\end{array}$ & $\begin{array}{l}\text { Lovelock (2010), } \\
\text { Zsolnai (2001) }\end{array}$ & $\begin{array}{l}\text { a földi élő és élettelen rendszerek szorosan összefüggenek, és együtt alkotják „Ga- } \\
\text { ia”-t, a komplex, önszabályozó rendszert, amely a földi élet számára optimális fizi- } \\
\text { kai-kémiai környezetet biztosít; } \\
\text { a Gaia-etika megköveteli, hogy a gazdasági tevékenységek ne sértsék a Föld } \\
\text { globális viszonyainak épségét }\end{array}$ \\
\hline & $\begin{array}{l}\text { morális önfel- } \\
\text { mentési straté- } \\
\text { giák }\end{array}$ & Bandura (2007) & $\begin{array}{l}\text { az ökológiailag romboló tevékenységek elkövetői a természetkárosító gyakorlatok } \\
\text { lelkiismereti kérdéseit egyéni és társadalmi szintü pszichés stratégiák segítségével } \\
\text { eltávolítják maguktól, hogy nem kelljen szembenézniük a következményekkel; } \\
\text { ilyen stratégiák lehetnek például: a károkozó tevékenységek elfogadtatása, igazolása } \\
\text { valamely magasabb társadalmi, nemzeti, gazdasági célra való hivatkozással, kedvező } \\
\text { összehasonlítással, megszépítő nyelvezettel, a káros hatások figyelmen kívül hagyá- } \\
\text { sával, minimalizálásával, vitatásával, az áldozatok dehumanizálásával vagy hibáz- } \\
\text { tatásával, a kedvezőtlen hírek közlőinek elhiteltelenítésével; az elszámoltathatóság } \\
\text { csökkentése a felelösség elhárításával és szétterítésével; } \\
\text { a természet és a jövő megőrzéséhez fel kell tudni ismerni, és hatástalanítani e straté- } \\
\text { giák alkalmazását }\end{array}$ \\
\hline & felelősségetika & $\begin{array}{l}\text { Jonas (1984), Zsolnai } \\
(2000,2014 a)\end{array}$ & $\begin{array}{l}\text { az emberi tevékenység természete, térbeli és időbeli hatóköre drámaian megválto- } \\
\text { zott, kibővült, ezért úffajta etikára, a felelősség elvének megerősítésére van szükség; } \\
\text { tevékenységünkkel összeadódó és visszafordíthatatlan károkat tudunk okozni, ezért } \\
\text { elengedhetetlen, hogy úgy éljünk, cselekedjünk, hogy ne veszélyeztessük az élet } \\
\text { jövőbeni fennmaradását a Földön; } \\
\text { emberi kötelesség a természeti létezők és a jövő generációk iránti nem viszonosságon } \\
\text { alapuló, gondoskodói hozzaállás vállalása }\end{array}$ \\
\hline & $\begin{array}{l}\text { „Univerzális } \\
\text { Elme”, termé- } \\
\text { szetes kiberneti- } \\
\text { kus rendszerek }\end{array}$ & Bateson (1972) & $\begin{array}{l}\text { a modern filozófiai és tudományos gondolkodásban megtalálható dualitás (például } \\
\text { ember - természet, társadalom - ökológia, elme - test) alapvetően hamis, mert a vi- } \\
\text { lág egyéneket, társadalmakat, ökoszisztémákat magában foglaló rendszerekböl épül } \\
\text { fel, amelyek egy magasabb szintü, átfogó rendszernek a részei; ezt sokan Istennek } \\
\text { nevezik, Bateson „Elmé”-nek; } \\
\text { a túlságosan célorientált nyugati gondolkodás korlátozott, mert leszűkíti a figyelmet, } \\
\text { az érzékelést, és téves elképzelést szül, hogy az ember minden rendszert képes uralni; } \\
\text { megoldás az alázat, a természetes önvezérelt rendszerek elfogadása, a kizárólag kog- } \\
\text { nitív alapú megismerés kiegészítése érzelmi, tudatalatti tényezők szintetizálásával; } \\
\text { ezekhez feltétel a szeretet kiterjesztése a társadalmak, ökoszisztémák felé, az elme } \\
\text { befogadóképességét tágító müvészetek, költészet, zene gyakorlása, kapcsolat ember } \\
\text { és természet között, illetve vallásgyakorlás, spiritualitás }\end{array}$ \\
\hline $\begin{array}{l}\text { Ökológiai } \\
\text { tudatosság és } \\
\text { spiritualitás / } \\
\text { A spiritualitás } \\
\text { fogalma }\end{array}$ & spiritualitás & $\begin{array}{l}\text { Bouckaert - Zsol- } \\
\text { nai }(2012), \text { Zsolnai } \\
(2014 b, 2015 b) \\
\text { European SPES } \\
(2017)\end{array}$ & $\begin{array}{l}\text { a természet megőrzéséhez, a valódi emberi szükségletek kielégítéséhez mértékletes, } \\
\text { gondos gazdálkodás szükséges, amely a gazdasági szereplők közjó szolgálatára irá- } \\
\text { nyuló belső motivációján, a minden érintett jóllétét figyelembe vevö többdimenziós } \\
\text { sikerdefinícióján, és az ezek mögött meghúzódó spiritualitáson alapulhat; } \\
\text { fogalma sokáig kizárólag a vallások kapcsolódott, ma már meghaladja az intézmé- } \\
\text { nyesült vallások kereteit; } \\
\text { fö összetevői: kapcsolódás a belső „én”-hez, egyetemes értékek keresése, minden } \\
\text { élővel való mély együttérzés, az élet forrásával való kapcsolatteremtés; } \\
\text { egy meghatározása: az élet értelmének különböző szociokulturális formákban való } \\
\text { keresése, amely összeköti az embereket minden élővel és Istennel, avagy a Végső } \\
\text { Valósággal }\end{array}$ \\
\hline $\begin{array}{l}\text { Ökológiai } \\
\text { tudatosság és } \\
\text { spiritualitás / } \\
\text { A spiritualitásalapú } \\
\text { vezetés }\end{array}$ & $\begin{array}{l}\text { spiritualitásala- } \\
\text { pú vezetés }\end{array}$ & $\begin{array}{l}\text { Pruzan }(2011,2015 a, \\
\text { 2015b) }\end{array}$ & $\begin{array}{l}\text { e koncepció szerint a vezetőket megélt spiritualitásuk belső forrásként képes vezetni, } \\
\text { miközben értelmet, célt és kiteljesedést keresnek a külső, üzleti világban és lelkiis- } \\
\text { meretük belső világában egyaránt; } \\
\text { ennek eléréséhez a vezetőképzés, a vezetési gyakorlat mellett az egyes vezetők } \\
\text { gondolkodásmódját is át kell alakítani, lelkiismeretüket megerősíteni, hogy képessé } \\
\text { váljanak tudatossá válni saját spiritualitásukról, a velük született isteniröl; } \\
\text { a valódi Én megtapasztalása minden ember és vezető számára elérhetö, amely ta- } \\
\text { pasztalat azután a döntésekben, a külső üzleti világban is megmutatkozik }\end{array}$ \\
\hline
\end{tabular}




\begin{tabular}{|c|c|c|c|}
\hline \multirow{3}{*}{$\begin{array}{c}\text { Ökológiai } \\
\text { tudatosság és } \\
\text { spiritualitás / } \\
\text { Ökológiai tudatos- } \\
\text { ság és vallás }\end{array}$} & $\begin{array}{l}\text { katolikus ke- } \\
\text { reszténység, } \\
\text { integrál ökoló- } \\
\text { gia, ökológiai } \\
\text { polgárság, } \\
\text { ökológiai spiri- } \\
\text { tualitás }\end{array}$ & Ferenc pápa (2015) & $\begin{array}{l}\text { Assisi Szent Ferenc tanításai által inspirált, tudományos igényü „Áldott légy” } \\
\text { (Laudato si’) kezdetű enciklikában; } \\
\text { ökológiai válság és társadalmi igazságosság kapcsolata, válságtünetek bemutatása, } \\
\text { megoldásként Szent Ferenc példája; } \\
\text { integrál ökológia: a kiszolgáltatott emberekre és természeti létezőkre odafigyelö, } \\
\text { humánus értékekkel (béke, öröm, önzetlenség, nyitottság önmagunk és a világ felé, } \\
\text { szellemi gazdagság az anyagi lemondáson keresztül) telített transzdiszciplináris } \\
\text { megközelítés } \\
\text { ökológia, gazdaság, természet- és társadalomtudományok, művészetek, oktatás } \\
\text { együttmüködése a méltányosságon, igazságosságon, mértékletes fogyasztáson, } \\
\text { természet önértékének elismerésén, holisztikus világszemléleten alapuló ökológiai } \\
\text { polgárság eszményéért; } \\
\text { az ember a nagylelkű gondoskodás, érzékenység, hála, önfeláldozó munka által felis- } \\
\text { meri, hogy egyetemes közösségben él az összes többi teremtménnyel }\end{array}$ \\
\hline & $\begin{array}{l}\text { Gandhi filozófi- } \\
\text { ája, nem-ártás } \\
\text { elve, önkéntes } \\
\text { szegénység }\end{array}$ & $\begin{array}{l}\text { Kovács - Ócsai } \\
(2015), \text { Timmerman } \\
(2015)\end{array}$ & $\begin{array}{l}\text { középpontja a nem-ártás (ahimsa) ősi védikus elve, és fontos inspiráció Szent Ferenc } \\
\text { természettel való alázatos, békés, együttérző kapcsolata, az egyszerüség, önkéntes, } \\
\text { méltóságteljes szegénység gyakorlása; } \\
\text { Igazság elérésének eszköze politikai, gazdasági, vallási, etikai, ökológiai kérdések- } \\
\text { ben is, személyes példamutatása a passzív ellenállásra; } \\
\text { cél az indiai szegénység enyhítése, alapvető emberi szükségletek kielégítése helyi } \\
\text { szinten önellátó, kisléptékü, decentralizált, ökológiailag fenntartható gazdaságokkal, } \\
\text { a korlátlan iparosítás, a profittermelő vállalatok uralmának és az erőforrások piaci } \\
\text { elosztásának visszaszorításával; } \\
\text { életünk célja önmagunk megismerése, ennek feltétele, hogy minden létezővel egynek } \\
\text { tekintsük magunkat, és az önzetlen szolgálat }\end{array}$ \\
\hline & $\begin{array}{l}\text { buddhista köz- } \\
\text { gazdaságtan, } \\
\text { környezeti } \\
\text { erények }\end{array}$ & $\begin{array}{l}\text { Schumacher (1991), } \\
\text { Kovács (2015), Ko- } \\
\text { vács - Ócsai (2015), } \\
\text { Zsolnai (2014c) }\end{array}$ & $\begin{array}{l}\text { Schumachert Gandhi felfogása jelentősen befolyásolta; } \\
\text { a buddhizmus nem foglalkozik külön a természettel, de környezeti attitüdje mégis } \\
\text { ökologikus (környezeti erények: nem-ártás, együttérzés, kis lépték, hála, megelége- } \\
\text { dés, egyszerüség. bölcsesség, tudatosság); } \\
\text { a buddhista életmód és stratégia legfőbb célja az emberi szenvedés megszüntetése a } \\
\text { Nemes Nyolcrétü Ösvény követésén keresztül; } \\
\text { a buddhista közgazdaságtan fő elemei a szenvedés minimalizálása, a vágyak egy- } \\
\text { szerüsítése, a nem-ártás gyakorlása, a valódi gondoskodás és nagylelkűség }\end{array}$ \\
\hline \multirow[t]{2}{*}{$\begin{array}{l}\text { Vállalkozások öko- } \\
\text { lógiai tudatossága }\end{array}$} & $\begin{array}{c}\text { vállalatok } \\
\text { közgazdasági / } \\
\text { moralista mo- } \\
\text { dellje, biocent- } \\
\text { rikus környezeti } \\
\text { etika, vállalatok } \\
\text { környezeti } \\
\text { lelkiismerete }\end{array}$ & $\begin{array}{l}\text { Goodpaster (1990), } \\
\text { Hoffman (1991), } \\
\text { Brenkert (1995) }\end{array}$ & $\begin{array}{l}\text { az üzleti világ a szabad piaci rendszerrel és a gazdasági társaságok nyereségmaxima- } \\
\text { lizáló természetével összefüggő sajátos etikája miatt nem képes környezetileg felelő- } \\
\text { sen müködni (közgazdasági modell); } \\
\text { a vállalatok morális cselekvők is, akiknek társadalmilag, környezetileg felelösen kell } \\
\text { viselkedniük a károkozás minimalizálására, a környezeti problémák megoldására } \\
\text { (moralista modell); } \\
\text { ehhez biocentrikus vállalati etikára, valamint a vállalat környezeti lelkiismeretéből } \\
\text { kifejlődő globális tudatosságra van szükség; } \\
\text { a gazdaság és a vállalatok belső törvényszerüségei (vállalkozási attitüdök, értékek, } \\
\text { bürokratikus üzleti struktúrák, rövid távú nyereség- és növekedésérdekeltség, } \\
\text { erőforráskihasználás, specializáció, árverseny) miatt a morális cselekvés nehéz, } \\
\text { alapvető változás kell: például elszámoltathatóság erősítése, a racionalitás kibővítése, } \\
\text { demokratizálás, nyitottság, környezetvédelem, fenntartható fejlödés }\end{array}$ \\
\hline & $\begin{array}{l}\text { indusztriális / } \\
\text { ökológiai világ- } \\
\text { szemlélet }\end{array}$ & $\begin{array}{l}\text { O'Riordan - Came- } \\
\text { ron (1994), Zsolnai } \\
(2001)\end{array}$ & $\begin{array}{l}\text { az ökológiai világszemlélet célja a harmónia elérése a természettel, amely nem csu- } \\
\text { pán erőforrás, mert minden faj egyenlö, minden természeti létezőnek önértéke van; } \\
\text { a Föld erőforrásai végesek, ez korlátot jelent a gazdasági növekedés számára, hiszen } \\
\text { a tudomány és a technológia nem tud mindent megoldani; } \\
\text { a fogyasztói vágyak helyett a szükségletekre kell koncentrálni, a fogyasztók képesek } \\
\text { és hajlandóak kontrollálni igényeiket; } \\
\text { a decentralizáltan elosztott hatalom figyelembe veszi az emberek és a természet } \\
\text { jogait }\end{array}$ \\
\hline
\end{tabular}




\begin{tabular}{|c|c|c|c|}
\hline \multirow[b]{2}{*}{$\begin{array}{l}\text { Vállalkozások öko- } \\
\text { lógiai tudatossága / } \\
\text { Vállalkozások és } \\
\text { fenntarthatóság }\end{array}$} & $\begin{array}{l}\text { fenntarthatóság } \\
\text { által vezérelt } \\
\text { vállalkozások }\end{array}$ & Parrish (2010) & $\begin{array}{l}\text { a fenntarthatósági értékekkel és motivációkkal rendelkező vállalkozók milyen szervezeti } \\
\text { tényezők segítségével tudnák értékeiket megvalósítani a versenypiacon? } \\
\text { céljuk az emberi és természeti erőforrások hosszú távú megőrzése; minden tevékenység } \\
\text { hasznának növelése prioritás a költséghatékonyság üldözése helyett; egyszerre több cél } \\
\text { kielégítő eredményére törekvés; a döntéseket az eredmények várható minősége alapján } \\
\text { minösítik; a hasznokat az elért érdemek és nem a hatalmi viszonyok alapján osztják el; } \\
\text { a vállalkozó akkor lesz sikeres, ha az értékei által generált szervezeti feszültségeket } \\
\text { eredményesen oldja meg az előző szempontok gyakorlati alkalmazásával }\end{array}$ \\
\hline & $\begin{array}{l}\text { fenntarthatósági } \\
\text { menedzsment, } \\
\text { „nagy szétkap- } \\
\text { csolódás”, üzleti } \\
\text { fenntarthatóság }\end{array}$ & $\begin{array}{l}\text { Dyllick - Muff } \\
\text { (2015) }\end{array}$ & $\begin{array}{l}\text { az egyre elterjedtebb nagyvállalati fenntarthatósági menedzsment nem javítja a Föld } \\
\text { ökológiai állapotát (,,nagy szétkapcsolódás”); } \\
\text { az üzleti modellek fenntarthatóság alapján négyfélék lehetnek: (1) napjaink uralkodó } \\
\text { üzleti felfogása, a „,business-as-usual” nem fenntartható; (2) a „,finomított tulajdonosi } \\
\text { értékteremtés” modelljei csak a gazdasági kockázatot vagy lehetőséget jelentö öko- } \\
\text { lógiai, társadalmi kérdésekre koncentrálnak alapvető stratégiájuk megváltoztatása } \\
\text { nélkül; (3) a „,triple bottom line” koncepció szerinti modellek gazdasági, társadalmi } \\
\text { és környezeti szempontokra is figyelnek; (4) a „valóban fenntartható” modellek a } \\
\text { negatív hatások minimalizálása mellett arra is összpontosítanak, hogyan érhetnének } \\
\text { el minél nagyobb pozitív hatást, a legégetőbb problémák megoldását formálják üzleti } \\
\text { modellekké; átláthatóságuk növelésével, jó gyakorlataik megosztásával, közös ipará- } \\
\text { gi önszabályozás és szabványok kialakításával, gazdaságon kívüli szereplökkel való } \\
\text { együttmüködésekkel a játékszabályok átírására törekednek }\end{array}$ \\
\hline \multirow{3}{*}{$\begin{array}{l}\text { Vállalkozások öko- } \\
\text { lógiai tudatossága / } \\
\text { Természet által ih- } \\
\text { letett vállalkozások, } \\
\text { környezeti felelős- } \\
\text { ségvállalás }\end{array}$} & $\begin{array}{l}\text { természet által } \\
\text { ihletett vállal- } \\
\text { kozások }\end{array}$ & Hofstra (2015) & $\begin{array}{l}\text { a természet kizsákmányolása, az ökoszisztémák pusztítása, a tőke és munkaerő természet- } \\
\text { nél többre értékelése helyett e vállalkozások megújító termék- és szolgáltatásinnovációkat } \\
\text { hajtanak végre, regenerálják a természetet, újra összekötik az embert a természettel; } \\
\text { elismerik, hogy az ember a természet része, amely minden fajért létezik, ezért a kor- } \\
\text { látozott eröforrásokat nem szabad csupán emberi igénykielégítésre használni, és csak } \\
\text { a Földet fenntartó (öko-hatékony és öko-hatásos) gazdaság engedhető meg; } \\
\text { a sikeres vállalkozó a természetet tanítójának tekinti, nem kizsákmányolja; egyszerre } \\
\text { veszi figyelembe a gazdaság, társadalom, természet hosszú távú érdekeit; számára az } \\
\text { üzleti érték tág értelmủ (gazdasági, ökológiai, erkölcsi, társadalmi és spirituális) }\end{array}$ \\
\hline & $\begin{array}{l}\text { vállalatok társa- } \\
\text { dalmi és kör- } \\
\text { nyezeti felelös- } \\
\text { ségvállalása }\end{array}$ & $\begin{array}{l}\text { Csutora - Kerekes } \\
\text { (2004), Kerekes - } \\
\text { Wetzker (2007) }\end{array}$ & $\begin{array}{l}\text { napjainkban környezeti biztonságot csak új vállalati etikai felfogás, a jogszabályokon } \\
\text { túlmutató társadalmi és környezeti felelösségvállalás jelenthet; } \\
\text { a társadalmi, környezeti elkötelezettség az elöírások teljesítésétől, a veszélyek mini- } \\
\text { malizálásán át az értékteremtés irányába fejlődik; } \\
\text { a környezeti elköteleződés alapjai a társadalmi normák (állami szabályozások, érin- } \\
\text { tettek elvárásai), technológiai lehetőségek (sikeres innovációk, ellátási láncon belüli } \\
\text { kapcsolatok természete), illetve a vállalatvezetők kognitív, magatartási jellemzöi } \\
\text { (morál, előfeltevések) }\end{array}$ \\
\hline & $\begin{array}{l}\text { környezettu- } \\
\text { datos válla- } \\
\text { latirányítás, } \\
\text { vállalatok társa- } \\
\text { dalmi felelössé- } \\
\text { ge (CSR), „Va- } \\
\text { lóban Felelős } \\
\text { Vállalat”" }\end{array}$ & Tóth (2007) & $\begin{array}{l}\text { a környezettudatos vállalatirányítás és a vállalatok társadalmi felelösségvállalása } \\
\text { operatív megközelítések, amelyek szükségesek, de nem elégségesek a fenntartható } \\
\text { fejlődéshez; } \\
\text { a stratégiai kihívás megoldásához „Valóban Felelős Vállalatra”, van szükség, amely- } \\
\text { nek öt alapelve: (1) szállitás minimalizálása, helyi piacok prioritása; (2) igazságos- } \\
\text { ság, méltányosság erősítése; (3) túlzott mértékủ nyereségnövelés elkerülése; (4) } \\
\text { optimális méret; (5) valódi szükségleteket kielégítő termékek; } \\
\text { vállalkozások fejlődése a „rendes, helyi vállalkozásoktól”, az „értékalapú szervezete- } \\
\text { ken”, „másért vállalkozókon” át a „,közösséget szolgáló vállalatok” felé; } \\
\text { a radikális változásokért a felelősséget az egyének (vállalatvezetők, tulajdonosok) } \\
\text { tudják vállalni; és akár alaptermékeik, stratégiájuk teljes átdolgozására, új vállalko- } \\
\text { zások alapítására is szükség lehet }\end{array}$ \\
\hline
\end{tabular}

\section{Összehasonlító elemzés, további kutatási irányok}

A Vezetéstudomány, mint a hazai szakirodalom meghatározó folyóiratának ökológiai tudatosság fogalmához legközelebb álló témájú tanulmányai összehasonlító elemzésekor a releváns cikkek kiválasztásához a szerző az EBSCO adatbázisok search.ebscohost.com honlap segítségével elérhető összevont keresőjét használta (a Budapesti Corvinus Egyetem Egyetemi Könyvtár hozzáférésén keresztül). A keresés során az „ökológia”, „tudatosság”, „ökológiai tudatosság”, „etika”, „értékek”, ,értékorientáció”, „fenntarthatóság”, illetve „,vál- lalatok társadalmi felelősségvállalása" keresőszavakat és ezek angol megfelelőit alkalmazta. A keresések eredményeként megtalált cikkek tartalmi áttekintése után a témához való kapcsolódásuk alapján öt tanulmányt emelt ki, amelyeket a fellelhető tartalmi hasonlóságok alapján megfogalmazható két dimenzió (az értékorientált müködéshez szükséges jellemzők és a hazai vállalatok működésének etikai, értékorientációs jellemzői) mentén jellemzett. (Az elemzett tanulmányok több esetben egymástól távol álló témákat ölelnek fel, ezért egyes kategóriák esetében több mező üresen maradt.) A cikkek összehasonlító elemzésének eredményeit a 2 . táblázat tartalmazza. 


\section{A Vezetéstudomány című folyóirat az ökológiai tudatosság témájához legközelebb álló tanulmányainak összehasonlító elemzése}

\begin{tabular}{|c|c|c|c|c|c|}
\hline $\begin{array}{l}\text { Forrás: } \\
\text { Téma: }\end{array}$ & Milton, 2010 & Bárth-Fehér, 2012 & Győri, 2012 & Szegedi, 2012 & $\begin{array}{c}\text { Kopfer-Rácz - Hofmeis- } \\
\text { ter-Tóth - Sas, } 2013\end{array}$ \\
\hline $\begin{array}{l}\text { Az } \\
\text { értékorientált } \\
\text { működéshez } \\
\text { szükséges } \\
\text { jellemzők, } \\
\text { viszonyok }\end{array}$ & $\begin{array}{l}\text { A CSR koncepció stra- } \\
\text { tégiai, üzleti szempontú, } \\
\text { instrumentális használa- } \\
\text { ta nem alkalmasa arra, } \\
\text { hogy a vállalatok társa- } \\
\text { dalmi felelősségvállalása } \\
\text { valóban a fenntartható- } \\
\text { ság irányába mutasson: } \\
\text { A vállalatok, a kormány- } \\
\text { zás és a szervezetek újra- } \\
\text { gondolására, újjáalkotá- } \\
\text { sára van szükség, amely } \\
\text { lehetővé teszi, hogy a } \\
\text { gazdasági rendszer az ed- } \\
\text { digiektől eltérően ne pusz- } \\
\text { títsa, hanem megőrizze, } \\
\text { helyreállítsa a természeti } \\
\text { környezetet, visszaadja } \\
\text { a munka valódi értelmét, } \\
\text { lehetővé tegye az értékes } \\
\text { innovációt és a természeti } \\
\text { korlátokat tiszteletben tar- } \\
\text { tó jóllétet (67. o.) }\end{array}$ & & $\begin{array}{l}\text { A közjó elérését célzó eti- } \\
\text { kai felelösség kudarcainak } \\
\text { megoldásához a gazdasági } \\
\text { élet alapvető átfogalmazá- } \\
\text { sára lehet szükség: } \\
\text { Az etika elsőfajú kudar- } \\
\text { ca esetén a vállalatveze- } \\
\text { tés számára fontosabb a } \\
\text { profitnövelés, mint a dön- } \\
\text { tések társadalmi, környe- } \\
\text { zeti hatásai (60. o.) } \\
\text { Az etika profitnövelő esz- } \\
\text { közként való használata a } \\
\text { másodfajú kudarc (60. o.) } \\
\text { A piaci, a kormányzati és } \\
\text { az etikai kudarcok elke- } \\
\text { rülése érdekében e rend- } \\
\text { szerek együttmüködése } \\
\text { mellett a gazdasági rend- } \\
\text { szer alapjainak átfogal- } \\
\text { mazására, az önérdek és } \\
\text { az egydimenziós teljesít- } \\
\text { ményértékelés helyett új, } \\
\text { holisztikus szemléletmód- } \\
\text { ra van szükség (63. o.) }\end{array}$ & & \\
\hline $\begin{array}{l}\text { A hazai } \\
\text { vállalatok } \\
\text { működésének } \\
\text { etikai, érték- } \\
\text { orientációs } \\
\text { jellemzői }\end{array}$ & & $\begin{array}{l}\text { A hazai vállalatok szán- } \\
\text { dékolt stratégiájában } \\
\text { egyre inkább megjelen- } \\
\text { nek a környezeti aspek- } \\
\text { tusok, ugyanakkor a kör- } \\
\text { nyezetvédelmi kérdéseket } \\
\text { széles körben menedzselö } \\
\text { vállalatok aránya alacsony } \\
\text { (53. o.) } \\
\text { Egyre több vállalat úgy } \\
\text { érzékeli, hogy a környe- } \\
\text { zetvédelemi kérdések } \\
\text { vállalati stratégiába való } \\
\text { integrálása alapvető el- } \\
\text { várás a piacon, melynek } \\
\text { figyelmen kívül hagyása } \\
\text { versenyhátrányt jelentene } \\
\text { a piacon (53. o.) } \\
\text { A társadalmi aspektusok } \\
\text { figyelembevétele és az } \\
\text { etikai normák intézmé- } \\
\text { nyesültsége a felelősnek } \\
\text { minősíthető vállalatoknál } \\
\text { is igen alacsony (53. o.) }\end{array}$ & & 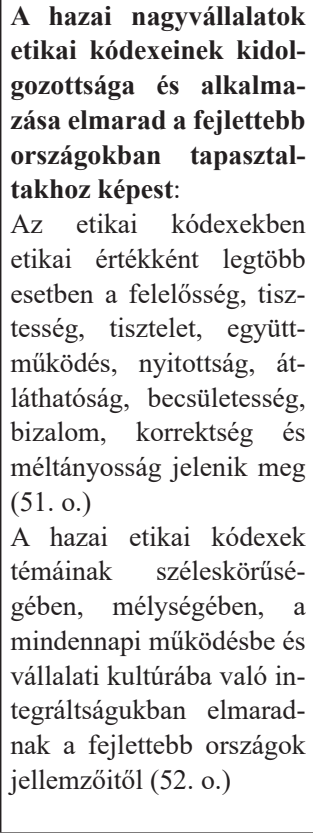 & $\begin{array}{l}\text { A magyar vállalkozók } \\
\text { szociokulturális beál- } \\
\text { lítódása jelentősen kü- } \\
\text { lönbözik a nagyvállalati } \\
\text { vezetőkétől és a magyar } \\
\text { társadalom összességé- } \\
\text { től: } \\
\text { A magyar KKV-vezetők } \\
\text { jobban preferálják az ön- } \\
\text { állóságot, az egyenlőséget, } \\
\text { mint a társadalom, jellem- } \\
\text { zőbbek rájuk a férfias érté- } \\
\text { kek (versenyszellem, tel- } \\
\text { jesítmény, anyagi siker), } \\
\text { de az együttmúködés, a } \\
\text { kockázatkerülés, a stabi- } \\
\text { litásra törekvés, a rövid } \\
\text { távú időorientáció és az } \\
\text { alacsony innovációs akti- } \\
\text { vitás is (9-10. o.) }\end{array}$ \\
\hline
\end{tabular}

Az összehasonlító elemzés eredménye alapján a következő jövőbeni kutatási irányok fogalmazhatók meg a nyitva hagyott kérdések, megoldatlan problémák mentén.

Kopfer-Rácz és társai (2013) hazai KKV-k szociokulturális tényezőit vizsgáló kutatásához kapcsolódva érdekes lenne megvilágítani, hogy a magyar kisvállalkozások többségének anyagisiker-orientáltsága, rövid távú időorientációja mennyire és hogyan egyeztethető össze az ökológiai tudatossághoz szükséges hosszú távú, ökologikus gondolkodásmóddal.
Bárth-Fehér (2012), Győri (2012) és Szegedi (2012) által nem érintett kérdés, hogy hogyan ítéljük meg az etika, az etikai rendszerek instrumentális használatát. Milton (2010) pedig azt a kérdést hagyja nyitva, hogyan képes a CSR-koncepció őszinte értékelköteleződéssé válni.

$\mathrm{S}$ végül a korábbi tapasztalatok alapján az értékorientáltság jellemzően inkább kisméretű vállalkozásoknál tapasztalható, ezért érdekes lehet összevetni a hazai értékorientált vállalkozások értékelkötelezettségét a hazai 
mikro-, kis- és középvállalkozások átlagos szociokulturális beállítódásával (Kopfer-Rácz et al., 2013).

A szerző által azonosított, a tárgyalt témakörökhöz kapcsolódó lehetséges jövőbeli kutatási irány még az ökológiailag fenntartható gazdasági cselekvés azonosítása és tanulmányozása. Ennek egy lehetséges módja az ökológiailag tudatosnak tekinthető progresszív hazai és külföldi vállalkozások példáinak empirikus vizsgálata, elemzése elsősorban a kiválasztott esetek és külső, belső összefüggéseik minél alaposabb megismerésére törekvő feltáró jellegü, kvalitatív módszertan segítségével. E vizsgálatok során az alábbi kutatási kérdések merülhetnek fel:

- melyek az ökológiailag tudatos vállalkozások fő jellemzői, alapértékei, üzleti modelljének leglényegesebb elemei,

- milyen a müködési környezete, kontextusa az ökológiailag tudatos vállalkozásoknak,

- az ökológiailag tudatos müködés a természetre nézve milyen elönyös hatásokkal járhat,

- foglalkoznak-e e vállalkozások az ökológiai átalakulás kérdéseivel, lehetségesnek tartják-e, és ha igen, milyen módon,

- gyakorlati példáikból merítve meghatározhatók-e ajánlások a fennálló gazdasági rendszer ökológiai átalakítására,

- felfedezhető-e új elméleti koncepció működésük vizsgálatából.

A lehetséges jövőbeli kutatási irányok a vállalkozások ökológiai tudatosságának tanulmányozása mellett az ökológiailag tudatos fogyasztás, illetve a kettő együttes, párhuzamos vizsgálatát is célozhatják. A szerző a bevezetésben részletesen, de a teljesség igénye nélkül felsorolta, hogy az ökológiailag tudatos fogyasztás témájának vizsgálatához milyen szakirodalom tanulmányozását tartja célszerünek, ezért itt csak a felmerült témákat emeli ki újra: (1) az ökológiailag kedvező változáshoz szükséges radikális életmódváltás, (2) a fenntartható fogyasztás lehetőségei, trendjei, (3) az értékek, különösen a környezeti értékek hatása a fogyasztói viselkedésre, (4) a fogyasztói értékek befolyása az ökológiai viszonyok romlására, (5) az ökologikus, fenntartható fogyasztás kapcsolata az értékekkel, illetve a tudatossággal, (6) a tudatosság, a környezetorientált viselkedés, az értékek és a spiritualitás, valamint ökológiai hatásaik kapcsolata. E kérdések tanulmányozásának lényeges szempontja az annak mélyebb megértéséhez való hozzájárulás, hogy a gazdaság fenntarthatóvá tételéhez radikális, az uralkodó materialista gazdasági paradigmán túlmutató változás szükséges, amelyben az ökológiai tudatosság erősödésének meghatározó szerepe van.

\section{Összefoglalás, következtetések, ajánlások}

A Föld jelenlegi ökológiai helyzete miatt a - mindezt túlnyomó részt okozó - fennálló társadalmi-gazdasági rendszer gyökeres átalakítása elengedhetetlennek tünik, az üzleti világban az etikai nézőpontok figyelembevételére, az ökológiai értékek tiszteletére és ökológiai tudatosságra van szükség. A szerző a nemzetközi szakirodalom elméleti koncepcióinak áttekintésével és néhány kapcsolódó hazai tanulmány rövid összehasonlító elemzésével a hazai szakirodalomban e téren tapasztalható hiány enyhítéséhez, valamint általánosságban az ökológiai válság megoldási lehetőségeinek kutatásához, illetve az ökológiai tudatosság irányába történő elmozduláshoz kívánt hozzájárulni. E hozzájárulás annak megértéséhez is szeretne kapcsolódni, hogy a gazdaság fenntarthatóvá tételéhez radikális, az uralkodó materialista gazdasági paradigmán túlmutató változás szükséges. Ennek első lépése pedig a tudatosságunk megváltoztatása.

Az ökológiai tudatosság szakirodalmának részletes áttekintése után a tanulmány zárásaként a különböző koncepciók legfőbb megállapításait, következtetéseit foglaljuk össze, amelyek egyben ajánlásként is szolgálnak a téma iránt érdeklődő, önmagukat fejleszteni, a világot jobbítani szándékozó olvasók számára.

Az ökológiai tudatosság, a természettel való harmónia az emberiség természetes állapota, amelytől a modern ember fizikailag, pszichológiailag, spirituálisan fokozatosan eltávolodott. A XX. század második felétől egyre súlyosbodó kedvezőtlen ökológiai, társadalmi, gazdasági hatások enyhítéséhez, visszafordításához új társadalmi, kulturális intézmények, új, ökológiai racionalitás, holisztikus énfelfogás szükségesek. A mélyökológia szerint a problémák gyökerének feltárása, valamint a gondolkodásmód radikális megváltoztatása mellett az ökológiai értékekkel összhangban álló személyes elköteleződések mentén való aktív cselekvés és felelősségvállalás a feladat. Az ökológiai közgazdaságtan hangsúlyozza, hogy a gazdaság az ökoszisztémák része, és a természeti létezők önértékét, a generációk közötti méltányosságot, a Föld eltartóképességét, a hosszú távon fenntartható fejlődést szem elött tartva gondosan kell használnunk és igazságosan elosztanunk az életfeltételeinket biztosító természeti szolgáltatásokat.

Az ökológiai tudatosság etikai vonzatai szerint csak az a dolog lehet helyes, amely megőrzi a természet integritását, stabilitását, szépségét (föld-etika), és az ökológiai lelkiismeret megerősítésére van szükség a természet és az ember kizsákmányolásának enyhítéséhez, megszüntetéséhez. A Földet és minden földi létezőt egy egységes, komplex, önszabályozó rendszernek tekintő Gaia-etika megköveteli, hogy a gazdálkodó szervezetek ne sértsék a globális természeti viszonyok és folyamatok épségét. Az ember drámaian megnövekedett és globális kiterjedésüvé vált befolyása, hatóereje visszafordíthatatlan károkat képes okozni, ezért emberi mivoltunkból származó kötelességünk, hogy tevékenységünkkel ne veszélyeztessük az élet jövőbeni fennmaradását a Földön (felelősségetika). Elengedhetetlen, hogy egyre inkább felismerjük, legyőzzük magunkban és magunk körül a morális önfelmentési stratégiák működését, amelyekkel a természetkárosító gyakorlatok lelkiismereti kérdéseit távolítjuk el magunktól. Arról is tudatosnak kell lennünk, hogy a túlzó módon célorientált nyugati gondolkodás korlátozott, mert leszükíti a figyelmet, az érzékelést, és azt a téves elképzelést szüli, hogy az ember minden rendszert képes uralni. Ennek feloldásához 
alázatra, a kizárólag kognitív alapú megismerés érzelmi, tudatalatti tényezőkkel történő szintetizálására, az ember természettel való kapcsolatának erősítésére van szükség, amelynek eszközei lehetnek a müvészetek, költészet, zene, vallások gyakorlása, a spiritualitás.

A spiritualitás a belső ,én”-hez való kapcsolódás, az egyetemes értékek keresése, a minden létezővel való mély együttérzés, az élet forrásával való kapcsolatteremtés, amely belső iránytüként a vezetőket is képes segíteni, miközben értelmet, célt és kiteljesedést keresnek a külső, üzleti világban és lelkiismeretük belső világában egyaránt (spiritualitásalapú vezetés). Minden ember, minden vezető képes a valódi Én megtapasztalására, illetve arra, hogy tudatossá váljon saját spiritualitásáról, a vele született isteniről, amely tapasztalat azután a döntésekben, a külső üzleti világban is megmutatkozik. A spiritualitás egyik legelterjedtebb vallási formája, a katolikus kereszténység Assisi Szent Ferenc tanításaiból merít az ökológiai válság megoldásának kidolgozásánál, amelyet összekapcsol a társadalmi igazságosság kérdésével. Humánus értékekkel telített transzdiszciplináris megközelítése (integrál ökológia) a méltányosságon, igazságosságon, mértékletes fogyasztáson, a természeti létezők önértékének elismerésén, holisztikus világszemléleten alapuló ökológiai polgárság eszménye felé közeledést tűzi ki célul, aki nagylelkü gondoskodás, érzékenység, hála, önfeláldozó munka által felismeri minden létezővel való közösségét. Gandhi filozófiájában a nem-ártás ősi elve, a természettel való alázatos, békés, együttérző kapcsolat, az egyszerüség, az önkéntes, méltóságteljes szegénység áll. Szerinte életünk célja önmagunk megismerése, amely a minden létezővel való egység érzésén és az önzetlen szolgálaton keresztül valósulhat meg. A buddhista közgazdaságtan fö elemei a szenvedés minimalizálása, a vágyak egyszerüsítése, a nem-ártás gyakorlása, a gondoskodás és nagylelküség. Gyakorlatában kiemelt szerepe van a környezeti erények (nem-ártás, együttérzés, kisléptéküség, hála, megelégedés, egyszerüség, bölcsesség, tudatosság) fejlesztésének.

A vállalkozások ökológiai tudatosságára koncentrálva a moralista modell szerint a vállalatok morális cselekvők, amelyeknek társadalmilag, környezetileg felelősen kell viselkedniük az általuk okozott károk minimalizálására, környezeti problémák megoldására törekedve. $\mathrm{E}$ célok eléréséhez eszközül nyitottságuk, elszámoltathatóságuk erősítése, racionalitásuk kibővítése, folyamataik demokratizálása, környezeti ügyekre, fenntartható fejlödésre való koncentrálásuk ajánlott. Ezekhez hasonlóan az ökológiai világszemlélet szerint a természettel való harmónia elérése a fontos, amelyben a vállalatok tudatában vannak, hogy a Föld erőforrásainak végessége miatt a gazdasági növekedés lehetőségei korlátozottak, nincs minden kérdésre technológiai megoldás, ezért inkább a fogyasztói szükségletekre, a decentralizált hatalomelosztásra, az emberek és a természet jogaira kell fókuszálniuk. A fenntarthatóság által vezérelt vállalkozások példájából a következők emelhetők ki: a költséghatékonyság üldözése helyett a pozitív hatások növelése, egyszerre több cél szerinti optimalizálás a pénzügyi nyereségmaximalizálás kizárólagossága helyett, a hasznok érdemek szerinti elosztása. A legégetőbb problémák megoldására kidolgozott „valóban fenntartható” üzleti modellek a tevékenységeik negatív hatásainak minimalizálása mellett a kiváltott pozitív hatások növelésére, átláthatóságuk fokozására, jó gyakorlataik megosztására, iparágon belüli és kívüli együttmüködések segítségével a gazdasági játékszabályok átírására törekednek. A természet által ihletett vállalkozások olyan termék- és szolgáltatásinnovációkat hajtanak végre, amelyek a természet kizsákmányolása, pusztítása helyett helyreállítják, megújítják azt. A természetből példát merítve csak ökohatékony és ökohatásos tevékenységeket folytatnak, amelyek egyszerre veszik figyelembe a gazdaság, társadalom, természet hosszú távú érdekeit, illetve tág értelemben vett (a gazdasági mellett ökológiai, erkölcsi, társadalmi és spirituális értékeket is magában foglaló) üzleti értéket teremtenek. A jogszabályi megfelelésen túlmutató társadalmi, környezeti felelősségvállalás alapjai a társadalmi normák, technológiai lehetőségek, illetve a vállalatvezetők kognitív, magatartási jellemzői (morál, előfeltevések). A fenntartható fejlődés eléréséhez azonban nem elégségesek a környezettudatos vállalatirányítás, a társadalmi felelősségvállalás operatív eszközei, stratégiai válaszokra van szükség, amelyek a „Valóban Felelős Vállalattá" válás irányába vihetnek. E vállalatok minimalizálják szállítási szükségleteiket, helyi piacokra koncentrálnak, erösítik müködésük során az igazságosság, méltányosság jelenlétét, tartózkodnak a túlzott mértékű nyereségnöveléstől, optimális méret elérése és megtartására törekednek, termékeik valódi szükségleteket elégítenek ki. Mindezek radikális változást igényelhetnek, akár alaptermékeik, alapvető stratégiájuk módosítását is szükségessé tehetik, amiért a vállalatvezetők, tulajdonosok vállalják a felelősséget.

Az összefoglalás terjedelme is mutatja, hogy az ökológiai tudatosság szakirodalmának áttekintése alapján bőséges mennyiségü következtetés, ajánlás áll rendelkezésre a vállalkozásuk ökológiai tudatosságán változtatni szándékozó vezetők számára. Talán egyszerre túl sok is. A szerző ezért legfőbb gyakorlati ajánlásként azt emeli ki, hogy a változást kezdjék legbelül, saját értékeik, gondolataik, érzéseik őszinte átvizsgálásával, feltérképezésével: melyek a személyes céljaik, prioritásaik, értékelkötelezettségeik, milyen a kapcsolatuk önmagukkal, a többi emberrel és a természettel. Ezek nem könnyü kérdések, de megkerülhetetlenek az ökológiai tudatosság felé vezető úton, mert minden más csak az ezekről való tudatosságuk függvényében változhat.

\section{Jegyzet}

${ }^{1}$ Az ökológia - a magyar tudományos életben elfogadott meghatározás szerint - az élőlények és környezetük közötti kölcsönhatások törvényszerüségeivel foglalkozó szünbiológiai (az egyed feletti szerveződési szintet vizsgáló) tudomány, amely az élőlény-populációk és a populációk alkotta rendszerek (társulások) környezettel való kölcsönhatásait, az elterjedésüket biztosító és korlátozó feltételeket, ezek produktivitásukra való hatásait vizsgálja (Juhász-Nagy, 1986; Hortobágyi - Simon, 2000).

${ }^{2}$ A tudatosságról mindannyiunknak vannak személyes tapasztalásai, a meghatározása azonban eltér a szerteágazó kutatási területeken, a keleti és a nyugati hagyományban, így nincs egységes meghatározása. A nyugati filozófiában az ókor óta az érdeklődés tárgyát képezi: Platón, majd Arisztotelész után Descartes, Locke, Leibniz és Kant is foglalkozott vele. A tudatosság kutatása a XIX. század végétől számos irányt 
vett, a pszichológiában Freud, a filozófiában Husserl és Heidegger, az 1980-as évektől pedig az agykutatás, neuropszichológia, idegtudomány vizsgálódásai is jelezték a tudatosság témája iránti interdiszciplináris érdeklődés megerősödését (Koch, 2004; Tononi-Kock, 2015; Gennaro, é. n.). Keleten a védikus (Chakraborty, 1995; Sen, 2008; Velmans, 2009; Pruzan, 2016) és a buddhista tanításokban (Rahula, 1974; Dalai Lama, 1995, 2005 idézi Marques, 2012; Nhat Hanh, 2008) is kiemelt fontosságú a tudatosság kérdése.

3 Kutatások (lásd többek között Carrington, 2016; Waters et al., 2016) támasztják alá, hogy az emberiség napjainkban már egy új földtörténeti korszakban, az antropocén korában él, amelynek fó jellemzője, hogy az ember a Föld csaknem minden pontját felfedezte, benépesítette már, tevékenységének hatása (Takács-Sánta (2010) alapján csak néhány hatást kiemelve: globális éghajlatváltozás, biológiai sokféleség csökkenése, erdőirtás, édesvíz-szűkösség) és kiterjedtsége pedig a földi viszonyokat meghatározó nagy természeti erőkhöz (például a nehézségi erő, kőzetlemezek mozgása, időjárás) mérhető. A földtudományokban egyelöre még nem történt meg az antropocén korszak hivatalos elismerése, és nincs általános egyetértés a kezdetét illetően sem (egyesek szerint a több mint 12 ezer évvel ezelőttre tehető újkőkori mezőgazdasági forradalomtól számítandó, mások az ipari forradalomtól, illetve a legtöbben a második világháború végi nukleáris tesztektől eredeztetik). Altalánosan elfogadott azonban, hogy az antropocén drámaian eltér a megelőző korszakoktól. A földi rendszerek korlátaiba (planetary boundaries (Steffen - Richardson et al., 2015)) ütköző, az 1950-es évektől egyre gyorsuló mértékben romló ökológiai, illetve kedvezőtlenebbé váló társadalmi és gazdasági folyamatok (ezt hívják a „nagy felgyorsulás" (great accelaration) jelenségének (Steffen - Broadgate et al., 2015)) miatt kiemelt figyelmet érdemel a vizsgálata, a társadalmi, gazdasági rendszerek múködésének mielőbbi lényegi megváltoztatása pedig elengedhetetlen.

\section{Felhasznált irodalom}

Ahuvia, A. C. - Wong, N. Y. (2002): Personality and values based materialism: their relationship and origins. Journal of Consumer Psychology. Vol. 12, No. 4, pp. 389-402.

Bandura, A. (2007): Impeding Ecological Sustainability through Selective Moral Disengagement. International Journal Innovation and Sustainable Development. Vol. 2, No. 1, pp. 8-35. Forrás: http://humanitieslab.stanford. edu/transformativedesign/admin/download.html? attachid=157880 letölve: 2017.02 .12 .

Bárth-Fehér, Sz. (2012): Fenntarthatóság a hazai vállalati gyakorlatban. Vezetéstudomány, XLIII. évf. 10. szám, pp. $44-54$.

Bateson, G. (1972): Steps to an Ecology of Mind. Collected Essays in Anthropology, Psychiatry, Evolution, and Epistemology. London: Jason Aronson Inc. Forrás: nomadicartsfestival.com/wp.../02/Gregory-BatesonEcology-of-Mind.pdf letöltve: 2017.02.09.

Beck, U. (1995): Ecological politics in an age of risk. Cambridge: Polity Press

Benson, K. R. (2000): The emergence of ecology from natural history. Endeavour, Vol. 24, No. 2, pp. 59-62.

Bouckaert, L. - Zsolnai, L. (2012): Spirituality and business: An interdisciplinary overview. Society and Economy, Vol. 34, No. 3, pp. 489-514.

Boulding, K. (1966): The economics of the coming spaceship Earth. Horn, G. (ford.): Az eljövendő „Földürhajó" gazdaságtana. In: Pataki, Gy. - Takács-Sánta, A. (szerk.) (2005)

Bragg, E. (1996): Towards ecological self: deep ecology meets constructionist self-theory. Journal of Environmental Psychology, Vol. 16. pp. 93-108.

Brenkert, G. G. (1995): The Environment, The Moralist, The Corporation and Its Culture. Business Ethics Quarterly, Vol. 5, No. 4, pp. 675-697.
Brown, P. G. - Timmerman, P. (eds.) (2015): Ecological Economics for the Anthropocene. An Emerging Paradigm. New York: Columbia University Press

Brunsø, K. - Scholderer, J. - Grunert, K. G. (2004): Closing the gap between values and behaviour - a means-end theory of lifestyle. Journal of Business Research, Vol. 57, No. 6. pp. 665-670.

Carrington, D. (2016): The Anthropocene epoch: scientists declare dawn of human-influenced age. The Guardian, 29 August 2016, Forrás: https://www.theguardian.com/environment/ 2016/aug/29/declare-anthropocene-epoch-expertsurge-geological-congress-human-impact-earth letöltve: 2018.07.11.

Carson, R. (2007): Néma tavasz. Páty: Katalizátor Kiadó

Chakraborty, S. K. (1995): Ethics in Management. Vedantic Perspectives. Oxford: Oxford University Press

Christopher, M. (1999): An Exploration of the „Reflex” in Reflexive Modernity - The Rational and Prerational Social Causes of the Affinity for Ecological Consciousness. Organization \& Environment, Vol. 12, No. 4, December, pp. 357-400.

Costanza, R. - Perrings, C. - Cleveland, C. J. (eds.) (1997): The development of ecological economics. Cheltenham: Edgar Elgar

Crutzen, P. J. - Stoermer, E. F. (2000): The Anthropocene. IGBP Global Change Newsletter, No. 41. pp. 17-18.

Csutora, M. (2012): One More Awareness Gap? The Behaviour-Impact Gap Problem. Journal Consumer Policy, Vol. 35, No. 1. pp. 145-163. Forrás: http://unipub. lib.uni-corvinus.hu/927/1/Csutora 2012 The\%20 Behaviour-Impact\%20Gap\%20Problem.pdf letöltve: 2017.02.24.

Csutora, M. - Hofmeister-Tóth, A. (szerk.) (2011): Fenntartható fogyasztás? A fenntartható fogyasztás gazdasági kérdései. Budapest: Budapesti Corvinus Egyetem

Csutora, M. - Kerekes, S. (2004): A környezetbarát vállalatirányítás eszközei. Budapest: KJK KERSZÖV. Forrás: unipub.lib.uni-corvinus.hu/411/1/ csutkeregyben.pdf letöltve: 2017.06.15.

Csutora, M. - Zsóka, A. (2014): May spirituality lead to reduced ecological footprint? Conceptual framework and empirical analysis. World Review of Entrepreneurship, Management and Sustainable Development, Vol. 10, No. 1. pp. 88-105.

Dalai Lama, H. H. (1995): The World of Tibetan Buddhism. In: Marques, J. (2012): Consciousness at Work: A Review of Some Important Values, Discussed from a Buddhist Perspective. Boston: Wisdom Publications

Dalai Lama, H. H. (2005): The Universe in a Single Atom: The Convergence of Science and Spirituality. In: Marques, J. (2012): Consciousness at Work: A Review of Some Important Values, Discussed from a Buddhist Perspective. Boston: Wisdom Publications

Daly, H. E. - Farley, J. (2004): Ecological economics: principles and applications. London: Island Press 
Daly, H. E. (2008): Frugality First. In: Bouckaert, L. - Opdebeeck, H. - Zsolnai, L. (eds.): Frugality: Rebalancing Material and Spiritual Values in Economic Life, Vol. 4, Bern: Peter Lang, pp. 207-226.

Devall, B. (1988): Simple in means, rich in ends: practicing deep ecology. Salt Lake City: Gibbs, Smith Publisher

Devall, B. - Sessions, G. (1985): Deep Ecology: living as if nature mattered. Salt Lake City: Gibbs Smith Publisher

Drengson, A. (1989): Beyond environmental crisis: from technocrat to planetary person. New York: P. Lang Publishers

Dyllick, T. - Muff, K. (2015): Clarifying the Meaning of Sustainable Business: Introducing a Typology From Business-as-Usual to True Business Sustainability. Organization \& Environment, Vol. 29, No. 2, pp. 156-174.

Eibel-Spanyi, K. - Hofmeister-Tóth, Á. (2013): The impact of values on consumer behaviour. International Journal of Economics and Business Research, Vol. 5, No. 4. pp. 400-419.

European SPES Institute (2017): Definition of spirituality. Forrás: http://www.euro spes.org/content/our-mission-spiritual-basedhumanism letöltve: 2017.02.21.

Feng Lin, Q. - Fyles, J. W. (2015): Following in Aldo Leopold's Footsteps. Humans-in-Ecosystem and Implications for Ecosystem Health. In: Brown, P. G. - Timmerman, P. (eds.): Ecological Economics for the Anthropocene. An Emerging Paradigm. New York: Columbia University Press, pp. 208-232.

Ferenc pápa (2015): Encyclical letter Laudato Si'. On Care for our Common Home. Forrás: http://w2.vatican. $\mathrm{va} / \mathrm{content} / \mathrm{dam} / \mathrm{francesco/pdf/encyclicals/documents}$ /papa-francesco_20150524_enciclica-laudato-si_ en.pdf letöltve: 2017.02 .14 .

Fraj, E. - Martinez, E. (2006): Environmental values and lifestyles as determining factors of ecological consumer behaviour: an empirical analysis. Journal of Consumer Marketing, Vol. 23, No. 3, pp.133-144.

Gennaro, R. J. (é. n.): Consciousness. The Internet Encyclopedia of Philosophy, ISSN 2161-0002. Forrás: http://www.iep.utm.edu/consciou/ letöltve: 2017.02.07.

Georgescu-Roegen, N. (2002): Az entrópia törvénye és a gazdasági probléma. Kovász, Vol. 6, No. 1-4., pp. 19-31. Forrás: http://kovasz.uni-corvinus.hu/kov12/ roegen.php letöltve: 2017.02.26.

Goodpaster, K. E. (1990): Can a Corporation Have an Environmental Conscience? In: Hoffman, W. M. - Frederick, R. - Petry, E. S.: Business, Ethics, and the Environment. New York: Quorum Books. idézi Brenkert, G. G. (1995)

Győri, Zs. (2012): Első- és másodfajú etikai kudarcok. Vezetéstudomány, XLIII. évf. 10. szám, pp. 56-62.

Hamilton, C. (2010): Consumerism, Self-creation and Prospects for a New Ecological Consciousness. Journal of Cleaner Production, Vol. 18, No. 6, pp. 571-575.

Hoffman, W. M. (1991): Business and Environmental Ethics. Business Ethics Quarterly, No. 1. pp. 169-184. idézi Brenkert, G. G. (1995).
Hofstra, N. (2015): Entrepreneurship Inspired by Nature. In: Zsolnai, L. (ed.): The Spiritual Dimension of Business Ethics and Sustainability Management. New York: Springer, pp. 159-166.

Hortobágyi, T. - Simon, T. (szerk.) (2000): Növényföldrajz, Társulástan és Ökológia. Budapest: Tankönyvkiadó

Hughes, J. D. (1991): The Psychology of Environmentalism Healing Self and Nature. Trumpeter, Vol. 8, No. 3. Forrás: http://trumpeter. athabascau.ca/index.php/trumpet/article/ view/458/759 letöltve: 2017.02.14.

Ims, K. (2015): Deep Ecology and Personal Responsibility. In: Zsolnai, L. (ed.): The Spiritual Dimension of Business Ethics and Sustainability Management. New York: Springer, pp. 47-56.

Jonas, H. (1984): The Imperative of Responsibility: In Search of an Ethics for the Technological Age. Chicago; London: The University of Chicago Press

Juhász-Nagy, P. (1986): Egy operatív ökológia hiánya, szükséglete és feladatai. Budapest: Akadémiai Kiadó

Kerekes, S. - Csutora, M. (szerk.) (2012): Fenntartható fogyasztás? Trendek és lehetőségek Magyarországon. Budapest: AULA Kiadó

Kerekes, S. - Wetzker, K. (2007): Keletre tart a „társadalmilag felelös vállalat” koncepció. Harvard Business Manager, IX. évf. 4. szám, április, pp. 36-47. Forrás: http://unipub.lib.uni-corvinus.hu/1349/1/ Kerekes_Wetzker_2007.pdf letöltve: 2017.06.15.

Koch, C. (2004): The Quest for Consciousness: A Neurobiological Approach. Englewood: Roberts and Company

Kollmuss, A. - Agyeman, J. (2002): Mind the gap: Why do people act environmentally and what are the barriers to pro-environmental behavior? Environmental Education Research, Vol 8, No. 3. pp. 239-260. Forrás: http://www.wec.ufl.edu/courses/wis6934/ Kollmuss\&Agyeman2002_pro-environmental\%20 behavior.pdf letöltve: 2017.02.24.

Kopfer-Rácz, K. - Hofmeister-Tóth, Á. - Sas, D. (2013): A hazai kis- és közepes vállalatok szociokulturális beállítódása a Hofstede-dimenziók mentén. Vezetéstudomány, XLIV. évf. 10. szám, pp. 2-11.

Kovács, G. (2015): Buddhist Spiritual Orientation to Nature and Sustainability. In: Zsolnai, L. (ed.): The Spiritual Dimension of Business Ethics and Sustainability Management. New York: Springer, pp. 57-67.

Kovács, G. - Ócsai, A. (2015): The Spirit of Non-violence and Peace in Business. In: Bouckaert, L. - Chatterji, M. (eds.): Business, Ethics and Peace. Bingley: Emerald Group Publishing, pp. 231-245.

Köves, A. - Mandják, T. (2014): Úton egy fenntartható gazdasági paradigma felé - A komplexitás befogadása a hálózati elméleteken keresztül. Vezetéstudomány, XLV. évf. 7-8. szám, pp. 69-75.

Leff, H. (1978): Experience, environment, and human potentials. New York: Oxford University Press

Leopold, A. (1949). The Ecological Conscience. In: Leopold, A. (1949): A Sand County Almanach. Oxford: 
Oxford University Press. Forrás: http://www.public. iastate.edu/ fridolph/leopold.html letöltve: 2017.01.29.

Lovelock, J. (2010): Gaia halványuló arca: Utolsó figyelmeztetés.Budapest: Akadémiai Kiadó

Marques, J. (2012): Consciousness at Work: A Review of Some Important Values, Discussed from a Buddhist Perspective. Journal of Business Ethics, Vol. 105, No. 1 (January 2012), pp. 27-40. Forrás: http://www.jstor. org/stable/pdf/41413206.pdf letöltve: 2017.02.07.

Meadows, D. L. et al. (1979): The limits to growth: A report for the Club of Rome's project on the predicament of mankind. London: Pan Books

Merton, T. (1968): The Ecological Conscience. (kivonat) The Catholic Worker. June 1968. Forrás: http://www.democraticunderground. com/discuss/duboard.php?az=view_all\& address $=115 \times 180150$ letöltve: 2017.01 .29 .

Mesarovic, M. - Pestel, E. (1974): Mankind at the turning point: The second report to the Club of Rome. New York: Dutton

Milbraith, L. (1989): Envisioning a sustainable society. Albany: State of New York Press

Milton, S. (2010): Some observation on CSR and strategic management. Vezetéstudomány, XLI. évf. 2. szám, pp. 59-67.

Morris, M. (2002): Ecological consciousness and curriculum. Journal of Curriculum Studies, Vol. 34, No. 5. pp. 571-587.

Naess, A. (1989): Ecology, community and lifestyle. Outline of an ecosophy. Cambridge: Cambridge University Press

Nhat Hanh, T. (2008): The Heart of the Buddha's Teaching. Transforming Suffering into Peace, Joy, and Liberation. E-book. London: Random House. Forrás: http://terebess.hu/zen /mesterek/Thich $\% 20 \mathrm{Nhat} \% 20 \mathrm{Hanh} \% 20-\% 20$ The $\% 20$ Heart $\% 20$ of $\% 20$ Buddha $\% 27$ s $\% 20$ Teaching.pdf letöltve: 2017.02.12.

O'Riordan, T. - Cameron, J. (1994): The History and Contemporary Significance of the Precautionary Principle. In: O’Riordan, T. - Cameron, J. (eds.): Interpreting the precautionary principle. London: Earthscan, pp. 1-30. In: Zsolnai, L. (2001)

O'Sullivan, E. V. - Taylor, M. M. (2004): Learning toward an ecological consciousness: selected transformative practices. New York: Palgrave Macmillan

Parrish, B. D. (2010): Sustainability-driven entrepreneurship: Principles of organization design. Journal of Business Venturing, Vol. 25, No. 5. pp. 510-523. Forrás: http://dx.doi.org/10.1016/j. jbusvent.2009.05.005 letölve: 2013.11.10.

Pataki, Gy. - Takács-Sánta, A. (szerk.) (2005): Természet és gazdaság. Ökológiai közgazdaságtan szöveggyüjtemény. Az ökológiai gondolat I. Budapest: Typotex Kiadó

Piskóti, M. (2015): A környezeti identitás szerepe a környezettudatos magatartásban - A mérési lehetőségek értékelése. Vezetéstudomány, XLVI. évf. 5. szám, pp. 13-23.
Polányi, K. (1976): Az archaikus társadalom és a gazdasági szemlélet. Budapest: Gondolat Kiadó

Polányi, K. (2004): A nagy átalakulás: Korunk gazdasági és politikai gyökerei. Budapest: Napvilág Kiadó

Princen, T. (1997): The shading and distancing of commerce: When internalization is not enough. Ecological Economics. Vol. 20, No. 3. pp. 235-253.

Pruzan, P. (2011): Spirituality as the basis for leadership. In: Boucaert, L. - Zsolnai, L. (eds.): The Palgrave handbook of spirituality and business. London: Palgrave, pp. 287-295.

Pruzan, P. (2015a): Spiritual-based Leadership: A Paradox of Pragmatism. In. Zsolnai, L. (ed.): The Spiritual Dimension of Business Ethics and Sustainability Management. New York: Springer, pp. 169-172.

Pruzan, P. (2015b): Further Reflections on Spirituality and Spiritual-based Leadership. In: Zsolnai, L. (ed.): The Spiritual Dimension of Business Ethics and Sustainability Management. New York: Springer, pp. 191-198.

Pruzan, P. (2016): Science and Spirituality. - Pruzan, P. (2016): Research Methodology. The Aims, Practices and Ethics of Science. Springer, Switzerland kiadatlan fejezete

Rockström, J. (2010): Let the environment guide our development. Forrás: http://www.ted.com/talks/ johan_rockstrom_let_the_environment_guide_our_ development letöltve: 2016.05 .15 .

Sanne, C. (2002): Willing consumers - Or locked-in? Policies for a sustainable consumption. Ecological Economics, Vol 42, No. 1-2. pp. 273-287.

Schumacher, E. F. (1991): A kicsi szép: Tanulmányok egy emberközpontú közgazdaságtanról. Budapest: KJK

Sen, A. (2008): The Vedic-Upanisadic concept of Brahman (the highest God). In: A. Eshleman (ed.): Readings in Philosophy of Religion: East Meets West. Malden, MA: Blackwell, pp. 43-51. In: Velmans, M. (2009)

Shove, E. (2004): Changing human behaviour and lifestyle: a challenge for sustainable consumption? In: Reisch, L. - Ropke, I. (eds.): The Ecological Economics of Consumption. Cheltenham: Edward Elgar

Steffen, W. - Broadgate, W. - Deutsch, L. - Gaffney, O. Ludwig, C. (2015): The trajectory of the Anthropocene: the Great Acceleration. The Anthropocene Review, Vol. 2. pp. 81-98.

Steffen, W. - Richardson, R. - Rockström, J. - Cornell, S. E. et al. (2015): Planetary Boundaries: Guiding human development on a changing planet. Science, 347: 736, 1259855, pp. $1-10$.

Sudbury-Riley, L. - Hofmeister-Tóth, Á. - Kohlbacher, F. (2014): A cross-national study of the ecological worldview of senior consumers. International Journal of Consumer Studies, Vol. 38, No. 5. pp. 500-509.

Szegedi, K. (2012): Hazai nagyvállalati etikai kódexek tartalmi elemzése. Vezetéstudomány, XLIII. évf. Különszám, pp. 47-55.

Takács-Sánta, A. (2004): The Major Transitions in the History of Human Transformation of the Biosphere. Human Ecology Review, Vol. 11, No. 1, pp. 51-66. 
Forrás: http://www.humanecologyreview.org/ pastissues/her111/111takacssanta.pdf letöltve: 2017.02.13.

Takács-Sánta, A (2010): Rapa Nui vagy Tikopia? Ökológiai válság és kiútlehetőségek címü humánökológia tanfolyam 2010/2011 előadásainak anyaga. Budapest

Timmerman, P. (2015): The Ethics of Re-Embedding Economics in the Real: Case Studies. In: Brown, P. G. - Timmerman, P. (eds.): Ecological Economics for the Anthropocene. An Emerging Paradigm. New York: Columbia University Press, pp. 21-65.

Tinbergen, J. (1979): A RIO-jelentés: A nemzetközi gazdasági rend átalakítása. Budapest: KJK

Tononi, G. - Koch, C. (2015): Consciousness: here, there and everywhere? Philosophical Transactions of the Royal Society. Biological Sciences. Forrás: http://rstb.royalsocietypublishing.org/ content/370/1668/20140167.full.pdf letöltve: 2017.02.09.

Tóth, G. (2007): A Valóban Felelős Vállalat - A fenntarthatatlan fejlödésről, a vállalatok társadalmi felelősségének (CSR) eszközeiről és a mélyebb stratégiai megközelítésről. Budapest: Környezettudatos Vállalatirányítási Egyesület, KÖVET-INEM Hungária. Forrás: http://www.kovet.hu/sites/default/ files/knowledge/a-valoban-felelos-vallalat.pdf letöltve: 2017.06.15.

Uhl, C. (2004): Developing ecological consciousness: path to a sustainable world. Lanham: Rowman \& Littlefield Publishers

Velmans, M. (2009): How to define consciousness-and how not to define consciousness. Journal of Consciousness Studies, Vol. 6, No. 5, pp. 139-156. Forrás: cogprints. org/6453/1/How_to_define_consciousness.pdf letöltve: 2017.02.09.

Waters, C.N. - Zalasiewicz, J. - Summerhayes, C. Barnosky, A.D. - Poirier, C. - Gatuszka, A. - Cearreta,
A. - Edgeworth, M. - Ellis, E.C. - Ellis, M. - Jeandel, C. - Leinfelder, R. - McNeill, J.R. - deB. Richter, D. - Steffen, W. - Syvitski, J. - Vidas, D. - Wagreich, M. - Williams, M. - Zhisheng, A. - Grinevald, J. Odada, E. - Oreskes, N. - Wolfe, A.P. (2016): The Anthropocene is functionally and stratigraphically distinct from the Holocene. Science, 8 January 2016, Vol. 351, Issue 6269. DOI:10.1126/science.aad2622 letöltve: 2018.07.11.

White, P. R. (2011): A Phenomenological Self-Inquiry into Ecological Consciousness. Ecopsychology, Vol. 3, No. 1, pp. 41-50. Forrás: letöltve: 2016.03.14.

Zsóka, Á. (2007): A fenntartható fogyasztás alapfeltétele: a környezettudatos egyéni magatartás. In: Gulyás, E. - Vadovics, E. (eds.): Fenntartható fogyasztás Magyarországon 2007. Budapest

Zsolnai, L. (2000): A döntéshozatal etikája. Budapest: Kossuth Kiadó

Zsolnai, L. (2001): Ökológia, gazdaság, etika. Budapest: Helikon Kiadó

Zsolnai, L. (2014a): Ethical Decision Making. In: Zsolnai, L.: Beyond Self. Ethical and Spiritual Dimensions of Economics. Bern: Peter Lang, pp. 45-64.

Zsolnai, L. (2014b): Ethics Needs Spirituality. In: Zsolnai, L.: Beyond Self. Ethical and Spiritual Dimensions of Economics. Bern: Peter Lang, pp. 79-83.

Zsolnai, L. (2014c): Buddhist Economic Strategy. In: Zsolnai, L.: Beyond Self. Ethical and Spiritual Dimensions of Economics. Bern: Peter Lang, pp. 119138.

Zsolnai, L. (2015a): Post-Materialistic Business: Spiritual Value-Orientation in Renewing Management. London: Palgrave Macmillan

Zsolnai, L. (2015b): Spirituality, Ethics and Sustainability. In: Zsolnai, L. (ed.): The Spiritual Dimension of Business Ethics and Sustainability Management. New York: Springer, pp. 3-11. 